\title{
Fluid processes in the Tesbihdere base-metal-Au deposit: Implications for epithermal mineralization in the Biga Peninsula, NW Turkey
}

Research article

\author{
Gulcan Bozkaya ${ }^{1}$, David A. Banks², Fatih Ozbas³ ${ }^{3}$ Jon Wallington ${ }^{4}$ \\ 1 Pamukkale University, Department of Geological Engineering, 20070, Denizli, Turkey \\ 2 School of Earth and Environment, University of Leeds, Woodhouse Lane, Leeds, LS2 9JT, UK \\ 3 Cumhuriyet University, Department of Geological Engineering, 58140 Sivas, Turkey \\ 4 Okyanus Mineral Mining Company, Balikesir Street, P.O. Box: 40, 17100, Canakkale, Turkey
}

Received 07 November 2013; accepted 31 January 2014

\begin{abstract}
Tesbihdere is one of a number of spatially close epithermal Cu-Pb-Zn-Ag-Au deposits hosted by andesites and rhyolites, typical of deposits in the Biga peninsula. Microthermometry of fluid inclusions shows a wide range of temperatures, $\sim 360-170^{\circ} \mathrm{C}$, and salinities, $\sim 10-0.5 \mathrm{wt} . \% \mathrm{NaCl}$, in the different deposits studied. Dilution of a moderately saline magmatic? fluid with meteoric water occurred at constant temperature indicating, the temperature of both fluids was controlled by the geological environment. Boiling was not a major factor, but did occur in very minor amounts. The large range of temperatures within individual samples can only reasonably be explained by variations from near lithostatic to hydrostatic pressure during vein and fracture opening. That this pressure decrease did not produce extensive boiling suggests that vein opening was gradual rather than aggressive, allowing the pressure and temperature decrease to follow a path close to the L-V boiling curve. P-T reconstruction places emplacement of these ore veins at between 300-500 m beneath the surface. Similarities of LA-ICPMS of fluid inclusions from Tesbihdere, Azitepe and Basmakci, supports the conclusion that they were part of the same contemporaneous mineralizing system. The fluids are dominated by $\mathrm{Na}$, with the concentrations of $\mathrm{K}>\mathrm{Ca}>\mathrm{Mg}$ combined equivalent to the concentration of $\mathrm{Na}$. The range of $\mathrm{K} / \mathrm{Na}$ ratios is not consistent with the fluid inclusion temperatures as the calculated temperatures are significantly higher indicating the fluids were not close to equilibrium with the enclosing rocks. Elevated $\mathrm{K}$ concentrations are consistent with acid-sulphate waters in shallow epithermal systems. Ore metals $\mathrm{Cu}, \mathrm{Zn}$ and $\mathrm{Pb}$ are present in significant concentrations $\sim 500,300$ and $200 \mathrm{ppm}$ respectively and the low Fe/Mn ratios are indicative of a relatively oxidising fluid. The negative $\delta^{34} \mathrm{~S}$ values of sulphides are consistent with boiling and oxidising redox conditions.
\end{abstract}

Keywords: Tesbihdere $\cdot$ NW Turkey $\cdot$ epithermal $\cdot$ LA-ICP-MS • fluid inclusion

(C) Versita Sp. z o.o.

\section{Introduction}

The Biga Peninsula, in northwest Turkey, is the location for a wide variety of different types of mineralization such as $\mathrm{Au}-\mathrm{Ag}$ deposits, porphyry $\mathrm{Au}-\mathrm{Cu}-\mathrm{Mo}$, Fe-skarns and epithermal $\mathrm{Pb}-\mathrm{Zn}-\mathrm{Cu}-\mathrm{Au}$, and since the $18^{\text {th }}$ century has attracted an increasing interest as a highly potential area for exploration and mining. Mining activities in the 
peninsula goes back to 3000 B.C. and covers the earlier era of the Bronze Age. Today it is still possible to see the remains of many mining activities in most locations.

The most important deposits in the peninsula are related to the "Tethyan Eurasian Orogenic Belt" [1] or "Tethyan Eurasian Metallogenic Belt" [2], extending from western Europe through Anatolia to Iran (Figure 1(a)), where it joins the Pacific Metallogenic belts to the east [3]. The Tethyan Eurasian Metallogenic Belt is currently one of the world's major metal producing belts [2]. There are diverse styles of mineralization present in the peninsula, but currently the most important are the epithermal $\mathrm{Au}-\mathrm{Ag}$ and epithermal $\mathrm{Pb}$ Zn-Cu-Au deposits such as Koru-Tesbihdere, Sahinli, Balcilar, Kumarlar, Balya, Bagirkacdere, Arapucandere, Kartaldag-Madendag, which are located from Lapseki to Edremit in the Biga Peninsula (Figure 1(b)). Almost all the deposits are found in the Tertiary calc-alkaline (i.e.andesite, dacite, rhyodacite and rhyolite) and alkaline (olivine basalts) volcanic and volcano-clastic rocks. Previous studies have been carried out on these deposits and different models for the origin of mineralization have been proposed by various authors (e.g., [2, 4-11, 1316]). However, in general there has been a lack of understanding of the fluids and the processes that were important for metal transport and deposition.

The Tesbihdere $\mathrm{Pb}-\mathrm{Zn}-\mathrm{Cu}-\mathrm{Au}$ deposit is located to the northeast of the town of Çanakkale in the Biga Peninsula. Mineralization is in a sequence of Upper Oligocene to Middle Miocene volcanics, pyroclastics of trachytic, trachyandesitic, dacitic, rhyolitic and rhyodacitic composition, and has been mined by Okyanus Minerals since 2007. The Tesbihdere deposit is a typical example of the volcanic-volcanoclastic hosteddeposits, which have been previously studied in terms of mineralogical, textural, fluid inclusion and geochemical characteristics in the nearby area (e.g., [6-8]). The deposit is one of a number of spatially close mineralized locations such as Basmacki, Azitepe, Sarioluk and Tesbihdere and was called the Sahinli, deposit which shares many features, not only within this area, but with similar styles of mineralization in the Biga Peninsula and western Turkey. The study by [15] concentrated on the other sectors of the Sahinli deposit but looked briefly at one sample from Tesbihdere. Their general conclusions related to the fluids was that there were two pulses of fluids at different temperatures related to different type of ores and that fluid mixing of low to moderate salinity meteoric and magmatic waters had occurred.

The aim of this study is to extend the microthermometry study of fluid inclusions from the closely related deposits of Tesbihdere, Basmacki and Azitepe and compare these to the previous study of the Sahinli deposit. However, we intend to provide a better understanding of the mineralizing fluids by determining in detail their composition, especially their ore metal concentrations, by using methods such as crush-leach and Laser Ablation ICP-MS (LA-ICP-MS) of individual fluid inclusions. This will allow us to more fully constrain the importance of the different fluids (meteoric, magmatic or mixtures) by direct analysis of fluids, instead of the limited composition that can be inferred from measured phase changes.

\section{Regional Geology}

The Biga Peninsula, which is part of the Tethyan Eurasian Metallogenic Belt, represents the westernmost extension of the Sakarya Zone of the Pontides at the intersection of Gondwana (African and Arabian plates) and Laurasia (Eurasian plate) (Figure 1(a)). The area has a complicated geologic and tectonic history due to the collision of the different continental fragments and their amalgamation due to the convergence between the Anatolide-Tauride platform (Gondwana) and the Pontides (Laurasia). The Peninsula can be tectonically subdivided into three zones going from the northwest to southeast. These are the Ezine zone (Permian meta-sedimentary and Permo-Triassic ophiolitic rocks), the Ayvacik-Karabiga zone (eclogite-bearing ophiolitic mélange and Late Triassic limestone blocks) and the Sakarya zone (Permian metamorphic rocks of the Kazdağ Group and Permo-Triassic sedimentary and magmatic rocks of the Karakaya Complex) (Figure 1(b); [17, 18]). Cenozoic volcanic and plutonic rocks, cover extensive areas and dominate the geology of the Biga Peninsula [19-21]. The Late Cretaceous-Tertiary period has been divided into four different sub-periods [17, 22, 23]: (1) the Late Cretaceous-Early Eocene (turbiditic sandstones and limestones), (2) Middle Eocene-Oligocene (andesitic lavas and tuffs, granite, granodiorite and limestones), (3) Miocene (granodiorite, rhyolitic and rhyodacitic pyroclastics and andesitic and dacitic lavas, and turbiditic clastics) and (4) Plio-Quaternary (fluvial sediments and lacustrine carbonates). Regional uplift occurred at the end of the Middle Oligocene, resulting in extensive erosion of the Eocene-Oligocene sequence [18]. This major uplift and erosional phase was followed by extensive Late Oligocene to Middle Miocene calc-alkaline magmatism. Granodioritic plutons and andesitic-dacitic volcanic rocks developed during the Eocene continuing with Oligocene granites, granodiorites, syenites and early Miocene rhyolites, dacites and calc-alkaline andesites [24-27]. In the Thrace basin and the Biga 

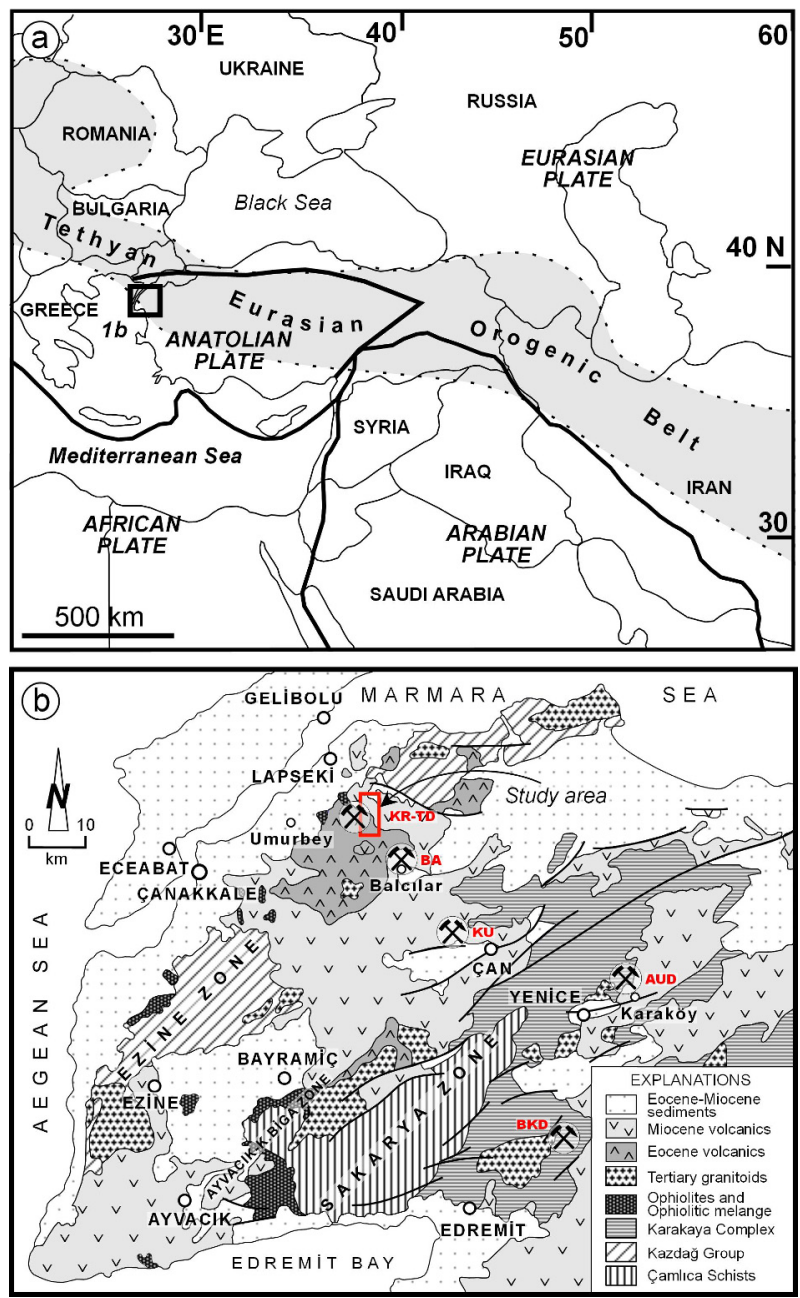

Figure 1. (a) Location of the study area within Turkey in relation to the boundaries of the major tectonic plates and Tethyan Eurasian Orogenic Metallogenic Belt (simplified after [55]). BA = Balcilar deposit, $\mathrm{KU}=$ Kumarlar deposit, AUD = Arapucandere deposit. (b) Simplified geological map of the Biga Peninsula.(KR-TD) Koru-Tesbihdere deposits.

Peninsula, Na-alkali basalts were emplaced during the late Miocene [28]. The sedimentary, volcano-sedimentary, volcanic and associated plutonic rocks in the Biga Peninsula are all related to the transition from a collisional to an extensional tectonic regime during the Cenozoic [19, 21, 26].

\section{Local Geology}

In the area of mineralization the lithological units are Eocene-Quaternary volcanic and sedimentary rocks (Figure 2). The lowermost unit is the Eocene Akçaalan andesite, which includes andesite, basaltic andesite, partly rhyodacite and dacite, containing pyroclastic and limestone intercalations in the upper part of the succession. Andesitic lavas have a predominantly hypohyaline and hypocrystalline porphyritic texture, with rare amygdales that include plagioclase and opasitic biotite and hornblende phenocrysts, within the volcanic glass, and a plagioclase microlite-bearing matrix (Figure 3(a),(b)). The volcanics have been completely argillized and sericitized in most of samples associated with mineralization, due to interaction with the hydrothermal fluids, and silica and chlorite can be found within the pore spaces. Within the limestone interlayers a 
fossil assemblage of gastropod shells and algae (Gypsina sp., Assilina sp., Rotalidae,) are present and confirm the Middle Eocene age [29]. This unit is unconformably overlain by Upper Oligocene-Lower Miocene Adadağı pyroclastics containing agglomerates, lapilli stone and ash tuffs with lava interlayers. Pyroclastic rocks contain agglomerates and tuffs of trachytic, trachyandesitic, dacitic, rhyolitic and rhyodacitic composition and andesitic and dacitic lavas. Vitroclastic porphyritic pyroclastic rocks contain volcanic glass and pumice, volcanogenic plagioclase, sanidine, quartz, biotite and volcanic rock fragments (Figure 3(c)-(f)). Pyroclastic rocks are classified as vitric/glassy, crystal and lithic ash tuffs, according to the Schmid [30] classification.

Argillization/sericitization, silicification and chloritization have replaced the volcanic glass, pumice and feldspar crystals (Figure 3(a)-(f)), around the zones of mineralization. The Miocene Dededağı dacite consists of dacitic and rare rhyodacitic lavas with a hypo-hyaline porphyritic texture. The matrix is heavily silicified and argillized, with widespread phenocrysts of plagioclase, hornblende, biotite, sanidine and quartz. Finally the Plio-Quaternary Karaömerler basalt cuts the Adadag pyroclastics and discordantly covers the older units. It consists of basaltic lavas with a hypo-hyaline porphyritic texture. Plagioclase and pyroxene (augite and aegirineaugite) phenocrysts are frequently present in the lavas.

\section{Mineralization \& ore petrography}

The $\mathrm{Cu}-\mathrm{Pb}-\mathrm{Zn}-\mathrm{Ag}-\mathrm{Au}$ mineralization in this area is primarily found in five discrete localities: going from north to south these are the Azitepe, Sarikayalar, Sarioluk, Basmakci and Tesbihdere sectors (Figure 2). In the Tesbihdere sector, the host rocks are andesitic lavas, whereas in the Azıtepe, Sartkayalar Basmakci and Sarıluk sectors the host rocks are rhyolitic, dacitic and trachyandesitic pyroclastic rocks with rhyolitic and dacitic lava intercalations (Figure 2).

Based on the field and petrographic observations, two styles of mineralization predominate in the andesitic lavas: vein-type and stockwork-type. (Figure 4(a),(b)). All mineralization in the investigated area exhibits faultcontrolled features: a brecciated matrix consisting of veins and vein fragments of medium to coarse-grained quartz. The ore veins are predominantly in WNW-ESE striking fault zones where the volcanic rocks have been extensively altered by the passage of hydrothermal fluids (Figure 4(c)-(f)) with extensive and widespread argillic alteration along with sericitization and silicification indicated by the presence of quartz, kaolinite, illite, mixed-layered illite-smectites and alunite [31]. In the larger quartz veins, several generations of quartz some of which are mineralized and some barren are observed. In our study we used quartz which was associated with sulphide mineralization and not barren quartz. The main gangue minerals are quartz, calcite and baryte. In the Tesbihdere sector, ore deposition is seen filling the cracks and open spaces within the altered pyroclastic host-rocks (Figure 5(a),(b)). The petrographic relation between the ore and quartz, and other gangue minerals, indicates they were deposited contemporaneously, but just after an early generation of quartz (I) and calcite (Figure 5(c),(d)) In the Azttepe sector, prismatic baryte crystals are also found as a gangue mineral in addition to quartz (I). Baryte-bearing gangue mineral occurrences are widespread in the nearby Koru and Balcular deposits $[6,7]$. Two different types of calcite are found in vein samples from Basmakci: (1) dark coloured with a high relief and (2) light coloured with a lower relief, the colour being related to the different $\mathrm{Fe}$ concentration. Euhedral quartz crystals, associated with sulphide deposition, were formed later than calcite and are believed to correspond to the second generation of quartz at the other locations.

The sulphide veins consist of primary chalcopyrite, galena, pyrite (Figure 5(e),(f)) and sphalerite with lesser amounts of tetrahedrite, chalcocite, covellite, goethite, digenite and cerrusite, which are mainly secondary. The paragenetic relationship between key hydrothermal stages is shown in Table 1. Pyrite is the earliest formed primary phase and the most common mineral occurring as euhedral cubes and subhedral crystals of variable size. Early pyrite is frequently observed to have been fractured and deformed by later phases. Chalcopyrite is the secondmost common mineral, occurring as anhedral crystals in association with galena and pyrite. Tetrahedrite and tennantite are present within fractures in chalcopyrite. Goethite is widespread typically replacing chalcopyrite (Figure 5(h)). Chalcocite and covellite are present along grain boundaries and fractures in chalcopyrite and considered to be of secondary origin (Figure 5(g)). Chalcopyrite is often associated with sphalerite and also occurs within sphalerite as chalcopyrite disease. Galena occurs with both chalcopyrite and sphalerite, and where supergene alteration has occurred is replaced by cerussite and anglesite.

\section{Analytical Methods}

\subsection{Microthermometry}

Microthermometry of the fluid inclusions was carried out using a Linkam THMS 600 heating-cooling stage. The 


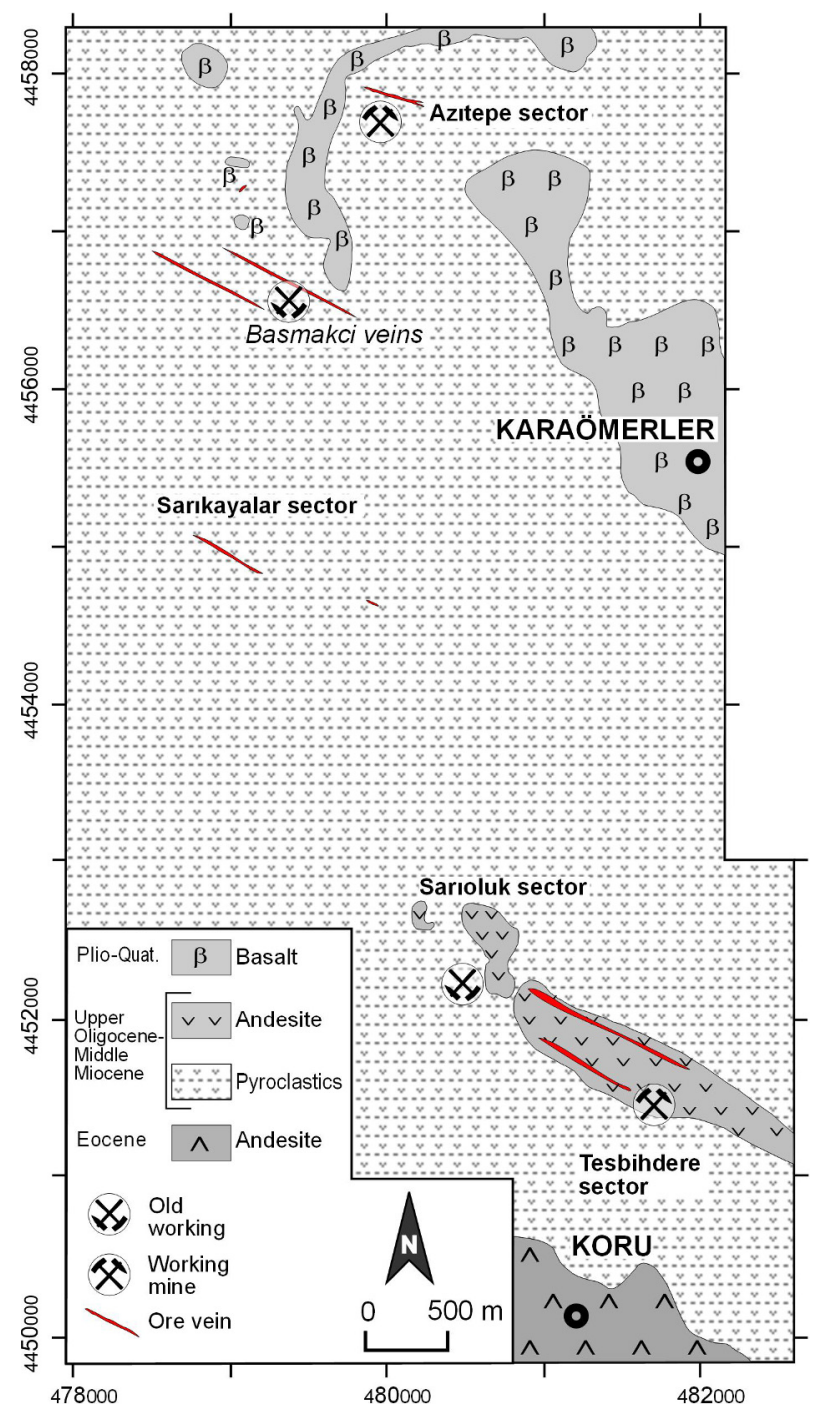

Figure 2. Geological setting of the mineralization at Tesbihdere, Basmakci and Azitepe.

temperature of phase changes for eutectic melting $\left(T_{e}\right)$, ice melting $\left(T_{m_{\text {ice }}}\right)$ and homogenization of the vapour phase $\left(T_{h}\right)$ were recorded. Phase transitions below $0^{\circ} \mathrm{C}$ are accurate to within $\pm 0.2^{\circ} \mathrm{C}$ based on calibration with pure $\mathrm{CO}_{2}$ and $\mathrm{H}_{2} \mathrm{O}$ standards, with a similar level of precision. Above $0^{\circ} \mathrm{C}$ accuracy was $\pm 3^{\circ} \mathrm{C}$ based on the melting point of pure solids and precision was $\pm 1^{\circ} \mathrm{C}$. The icemelting temperatures were converted to salinities using the equation of [32] and assuming the fluid composition is represented by the $\mathrm{H}_{2} \mathrm{O}-\mathrm{NaCl}$ system.

\subsection{LA-ICP-MS}

Laser-ablation inductively-coupled mass-spectrometry (LA-ICP-MS) using an Agilent 7500c mass spectrometer, combined with a Geolas ablation system was used to determine the composition of individual fluid inclusions or small groups of related inclusions. The Geolas ablation system uses a Compex 103 ArF excimer laser at a wavelength of $193 \mathrm{~nm}$, delivering an energy density of between $10-15 \mathrm{~J} \mathrm{~cm}^{-2}$ on the sample surface at a pulse frequency of typically $5 \mathrm{~Hz}$ with spot sizes of $25 \mu \mathrm{m}$ or occasionally $50 \mu \mathrm{m}$. The spot size was determined by the 

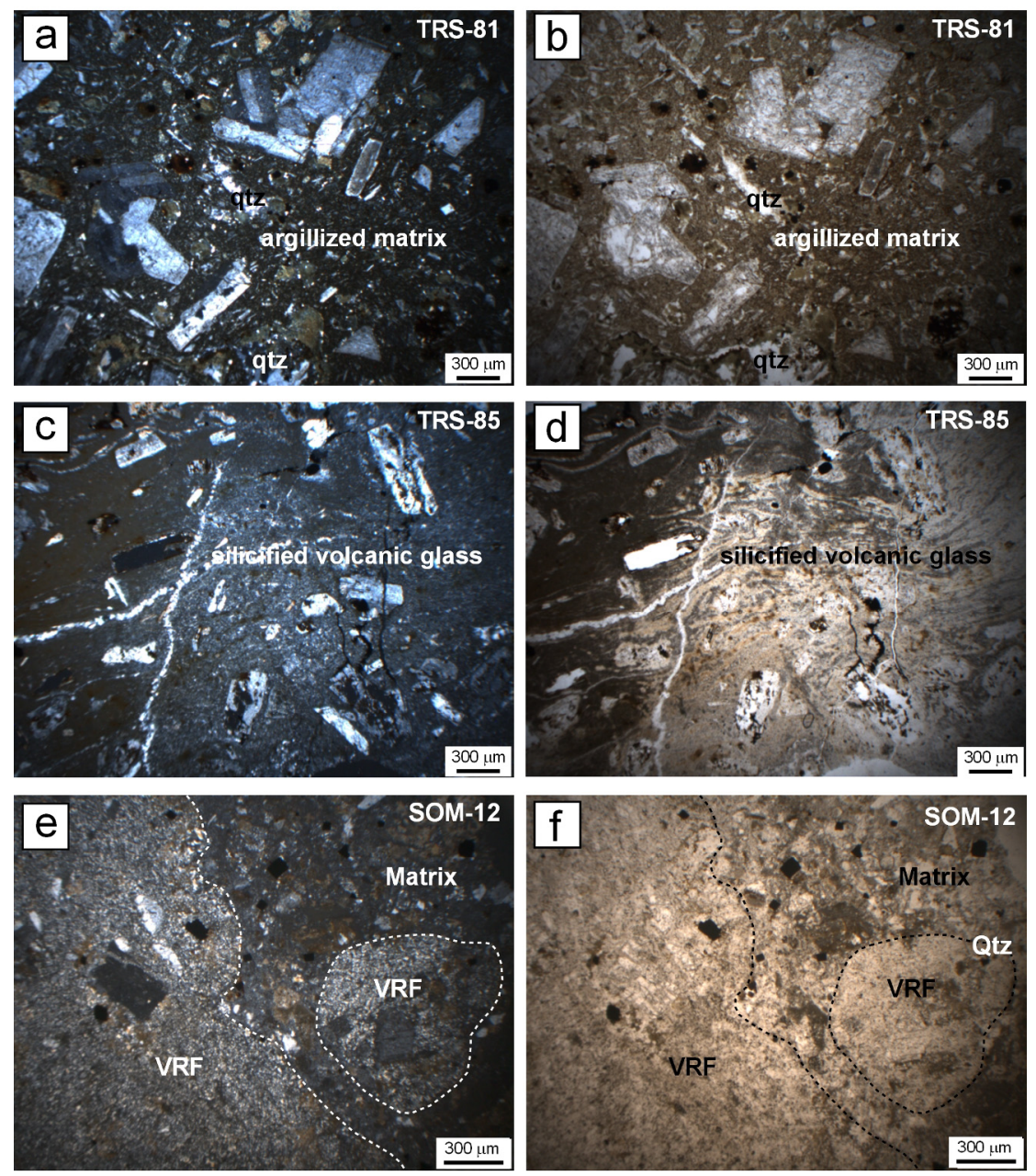

Figure 3. Photomicrographs of representative lithologies form the Tesbihdere deposit. (those on the left are in crossed polars, those on the right are in plane polarised light). (a,b) Plagioclase phenocrysts and opasitised amphiboles and biotite in a argillized volcanic matrix of altered andesite. (c,d) Silicified volcanic glass with a pumice like texture in a vitric or glassy ash tuff, (e,f) Volcanic rock fragments (VRF) within the altered matrix of a lithic ash tuff (Sarioluk).

size of the inclusions or groups of small inclusions. The ablated material was transported from the ablation cell to an Agilent 7500c ICP-MS using $99.9999 \%$ He flowing at

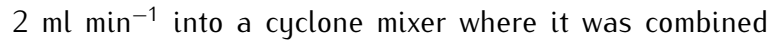
with the Ar carrier gas flowing at $1.02 \mathrm{ml} \mathrm{min}{ }^{-1}$. The function of the mixer is to prolong the signal from the ablated inclusions and improve precision by increasing the number of cycles through the mass range selected and therefore the number of determinations of the elemental ratios relative to $\mathrm{Na}$. The instrument was operated in reaction cell mode using $2.5 \mathrm{ml} \min ^{-1} 99.9999 \% \mathrm{H}_{2}$ to remove interferences from ${ }^{40} \mathrm{Ar}$ on ${ }^{40} \mathrm{Ca}$ and from ${ }^{56} \mathrm{ArO}$ on ${ }^{56} \mathrm{Fe}$. Calibration of the element/ $\mathrm{Na}$ intensity ratios to weight/weight ratios was achieved using the NIST glass standard SRM-610 and the soda lime standard SRM1412 (for K/Na ratios that were close to 1). SRM-610 was used to check for instrumental drift, which was found to be insignificant over each day's analysis. Integration of the standard and sample signals was achieved with the SILLS software package [33]. Full details of the analytical protocols and calibration of the instrument are presented in [34]. 

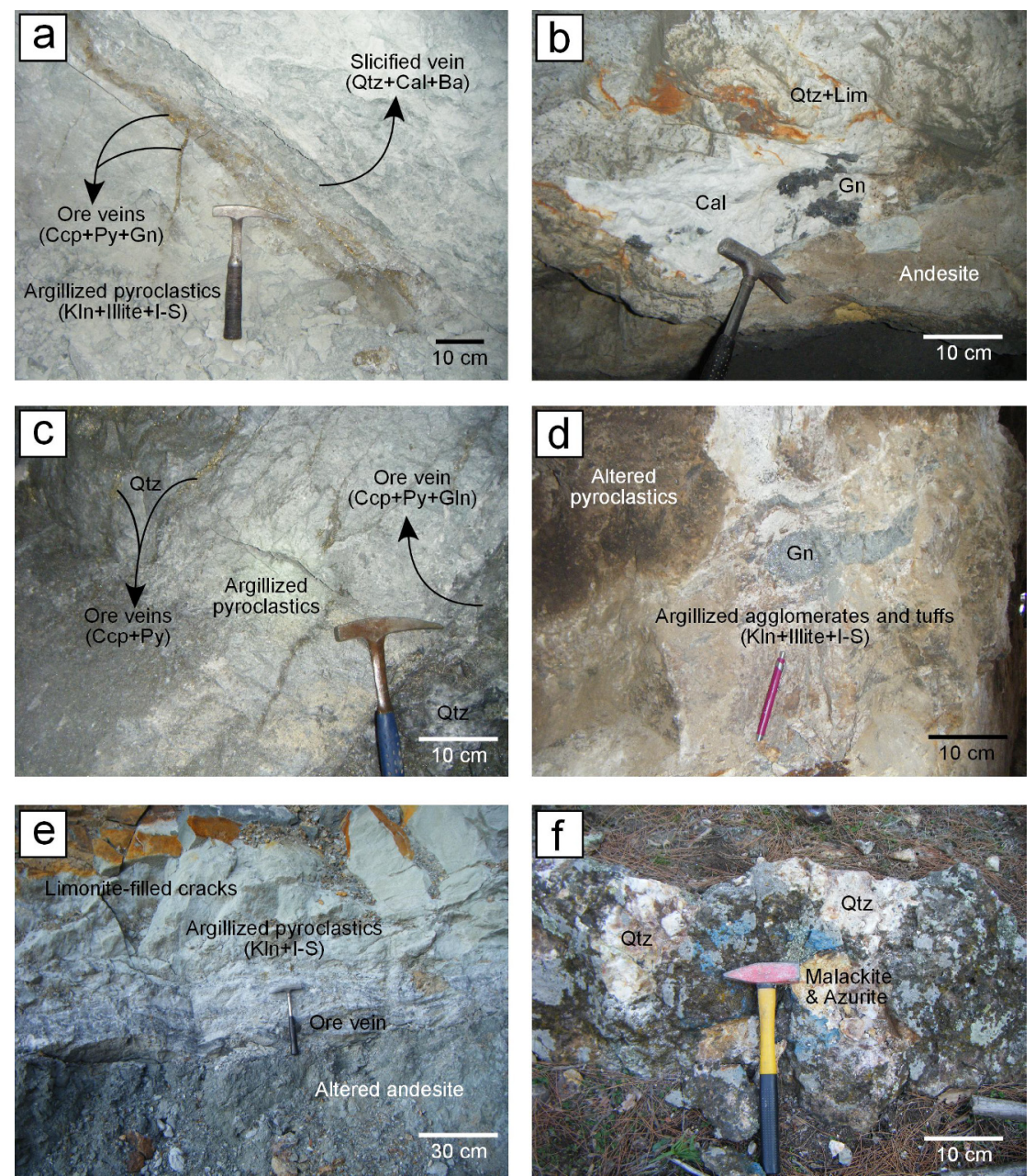

Figure 4. Field observations of host-rock and ore bodies (a) Vein-type chalcopyrite-rich ore and quartz-rich gangue within the altered pyroclastic rocks (Tesbihdere sector, gallery), (b) Andesite-hosted ore containing galena, calcite and quartz and limonite (Basmakci sector), (c) Argillized silica-rich pyroclastic rocks cut by chalcopyrite veins (Tesbihdere sector, gallery), (d) Galena within altered agglomerate and lapilli stones (Sarıoluk sector), (e) Ore vein located along the boundary of argillized pyroclastic rocks and altered andesites (Azitepe sector), (f) Silicified ore with supergene copper carbonate (Azıtepe sector) (Ccp: chalcopyrite, Py: pyrite, Gn: galena, Qtz: quartz, Cal: calcite, Ba: barite, Lim: limonite, KIn: kaolinite, I-S: mixed-layered illite-smectite).

\subsection{Crush-Leach}

The method described by [35] was used to analyse portions of the different veins for anions $\left(\mathrm{F}, \mathrm{Cl}, \mathrm{Br}, \mathrm{SO}_{4}\right)$ and alkali's $(\mathrm{Na}, \mathrm{K})$. Samples of the veins were crushed to a size of $1-2 \mathrm{~mm}$ and extraneous grains removed prior to the samples being cleaned by boiling in $18.2 \mathrm{M} \Omega$ water several times to clean any contamination from the surface and then dried. The samples were dry crushed to a fine powder in an agate pestle and mortar, then transferred to a Sterlin container and leached with approximately $6 \mathrm{ml}$ of $18.2 \mathrm{M} \Omega$ water. The liquid was filtered through a $0.2 \mu \mathrm{m}$ nylon syringe filter and an aliquot analysed for anions with a Dionex DX 500 ion chromatograph. Na and K were determined by flame emission spectroscopy. The detection limit for anions in the leachate solutions was $\sim 10 \mathrm{ppb}$ for $\mathrm{Cl}$ and $\mathrm{SO}_{4}, \sim 1 \mathrm{ppb}$ for $\mathrm{Br}$ and $5 \mathrm{ppb}$ for $\mathrm{F}$. $\mathrm{Na}$ and $\mathrm{K}$ had detection limits of approximately $25 \mathrm{ppb}$. Molar ratios of $\mathrm{Cl} / \mathrm{Br}$ are quoted with an error of less than $5 \%$ based on replicate analyses of a standard seawater sample (Ocean scientific GPS-1 Atlantic seawater) at a $\mathrm{Br}$ concentration in the standard solution of $50 \mathrm{ppb}$. 

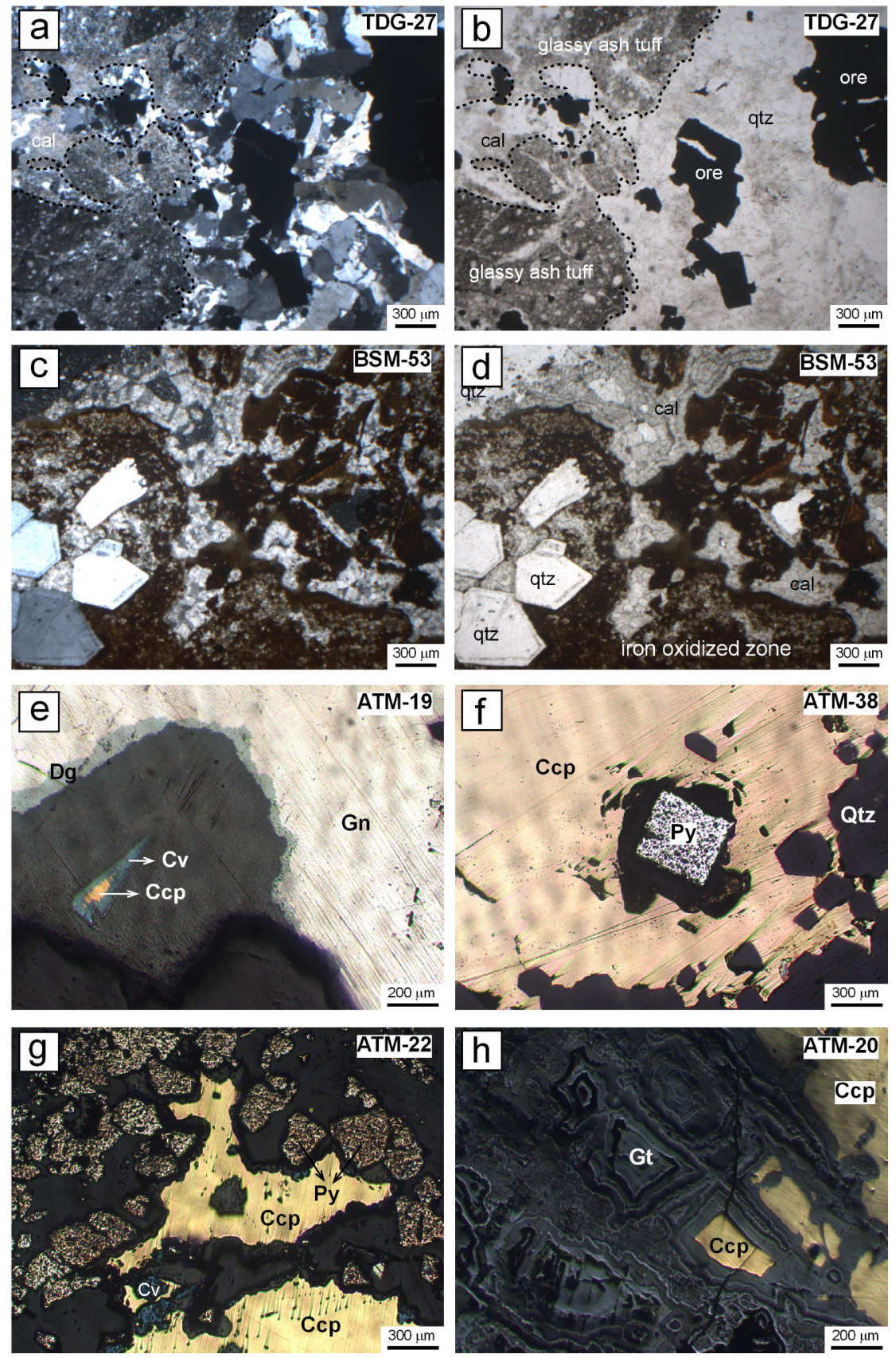

Figure 5. Photomicrographs of transmitted (a-d) and reflected-plain polarized light (e-g) images of the representative ore samples from Tesbihdere deposit. (a-b) Quartz and ore mineral associations as filling material within the cracks of glassy ash tuff in Azitepe sector (left is crossed nicols, right is open nicol), (c-d) Euhedral quartz crystals (quartz (II) were developed after calcite from ore-bearing iron-oxidized pyroclastic rock sample in Basmakci sector (left is crossed nicols, right is open nicol), (e) supergene alteration that caused an intense replacement of galena by digenite, (f) Euhedral pyrites are surrounded by chalcopyrite ( $\mathrm{g}$ ) cataclastic pyrites are filled by chalcopyrite, (h) Goethite is replaced with altered chalcopyrite (qtz: quartz, cal: calcite, brt: barite, Gn: galena, Ccp: chalcopyrite, Py: pyrite, Cv: covellite, Dg: Digenite, Gt: goethite). 
Table 1. Paragenetic sequence of the ore and gangue minerals from the Tesbihdere deposit.

\begin{tabular}{|c|c|c|c|}
\hline \multirow{2}{*}{ Mineral } & \multicolumn{2}{|c|}{ Hydrothermal } & \\
\hline & Stage 1 Stage 2 & Stage 3 & \\
\hline Barite & & - & \\
\hline Pyrite & - & & \\
\hline Galena & & - & \\
\hline Sphalerite & - & - & \\
\hline Chalcopyrite & -- & ـ & \\
\hline Tetrahedrite-Tennantite & & & - \\
\hline Quartz & - & - & - \\
\hline Calcite & - & & \\
\hline Digenite & & & - \\
\hline Covellite & & & - \\
\hline Chalcocite & & & \\
\hline Cerussite & & & - \\
\hline
\end{tabular}

\subsection{Sulphur isotopes}

Sulphur isotope studies were carried out on the galena and chalcopyrite separates hand-picked from the ore samples of the Tesbihdere and Azitepe sectors (Table 4). The sulphur isotope analyses were performed at the Stable Isotope Laboratories of Georgia University (Athens, USA). Sulphide samples were prepared for analysis following the method of [36] with the following modifications. The silica glass tube and reaction mixture are heated up to $950^{\circ} \mathrm{C}$ and kept at this temperature for 15 minutes. The evolved $\mathrm{SO}_{2}$ is continuously condensed into a U-shaped trap immersed in liquid nitrogen. The evolution of $\mathrm{SO}_{2}$ from sulphate minerals starts at around $600^{\circ} \mathrm{C}$ and reaches a maximum near $750^{\circ} \mathrm{C}$ as found for $\mathrm{BaSO}_{4}$ by [36]. In contrast, sulphide minerals start to produce $\mathrm{SO}_{2}$ at $750^{\circ} \mathrm{C}$ with maximum evolution near $950^{\circ} \mathrm{C}$. Sulphide minerals containing two sulphur atoms in their chemical formula such as pyrite and chalcopyrite display two maxima in $\mathrm{SO}_{2}$ evolution during the reaction. One occurs when the temperature reaches $950^{\circ} \mathrm{C}$ and the other 5 to 10 minutes later. After the reaction, the $\mathrm{SO}_{2}$ gas is purified to remove $\mathrm{CO}_{2}$ and $\mathrm{H}_{2} \mathrm{O}$ using vacuum distillation at the temperature of $n$-pentane and alcohol slush. Despite their differences, the reaction temperatures for sulphate and sulphides are sufficiently high that the oxygen isotope composition of the evolved $\mathrm{SO}_{2}$ should be uniform.

\section{Results}

\subsection{Microthermometry}

Examples of the petrography of the fluid inclusions are shown in Figure 6(a)-(f). Inclusions are primarily $\mathrm{L}-\mathrm{V}$, but with variable $\mathrm{L} / \mathrm{V}$ ratios usually dominated by $L_{i} \mathrm{~V}$ but in some instances $\mathrm{V}$-rich inclusions are observed and very rarely L-V-solids (halite?) inclusions. The inclusions are typically 20-30 $\mu \mathrm{m}$ in size with many $\sim 10 \mu \mathrm{m}$ or less. Isolated inclusions are typically larger than inclusions that are part of growth zones or pseudosecondary planes. Most inclusions appear either primary (P) or pseudosecondary (PS) and some clear secondary (S) trails are present. However, for the majority of inclusions there is no gross difference in the range of $\mathrm{L} / \mathrm{V}$ ratios of the different inclusion types. Fluid inclusion arrays (FIA's) normally have inclusions with consistent $L / \mathrm{V}$ ratios, but different FIA's can have to different $L / V$ ratio. There are also a number of FIA's where the L/V ratio is markedly different and rare examples have been observed (Figure 6(e),(f)) where an FIA appears to contain a boiling assemblage with L-V, V-rich and L-V halite?

A summary of the microthermometry results of quartz hosted fluid inclusions from Tesbihdere, Basmakci and Azitepe are presented in Table 2. The inclusions measured were predominantly primary, but where secondary or pseudosecondary inclusions were measured the results are not discernibly different. Eutectic melting was difficult to observe, however the most reliable results are $-58 /-55^{\circ} \mathrm{C}$ indicative of $\mathrm{CaCl}_{2}$ in addition to $\mathrm{NaCl}$ in the fluid, but the inclusions did not go brown on freezing. Hydrohalite dissolution was not observed, so an estimate of the $\mathrm{CaCl}_{2}$ content was not obtained from microthermometry. The final ice melting temperatures for Tesbihdere and Azitepe are quite variable ranging from -7.4 to $-0.3^{\circ} \mathrm{C}$ with those from Basmakci confined to between -3.2 to $-2.0^{\circ} \mathrm{C}$. This corresponds to a range in salinities from 11 to $0.5 \mathrm{wt} \% \mathrm{NaCl}$ equiv. based on [34]. The homogenization temperatures from the different locations (Figure 7) all have a large, and similar, range for either the $\mathrm{P}$ or PS inclusions that cannot be accounted for by normal uncertainties during measurement. At Tesbihdere the $T_{h}$ values are between 152 and $365^{\circ} \mathrm{C}$, Basmakci between 178 and $272^{\circ} \mathrm{C}$ and Azitepe between 244 and $335^{\circ} \mathrm{C}$. The only notable difference between the three locations is that samples from Basmakci have distinctly lower homogenization temperatures.

In Figure 8, pairs of homogenisation and final ice melting temperatures are plotted. The majority of the data from Tesbihdere and Azitepe show a general linear trend at relatively constant temperature from saline fluids to almost pure $\mathrm{H}_{2} \mathrm{O}$ fluids. The data effectively defines a dilution 

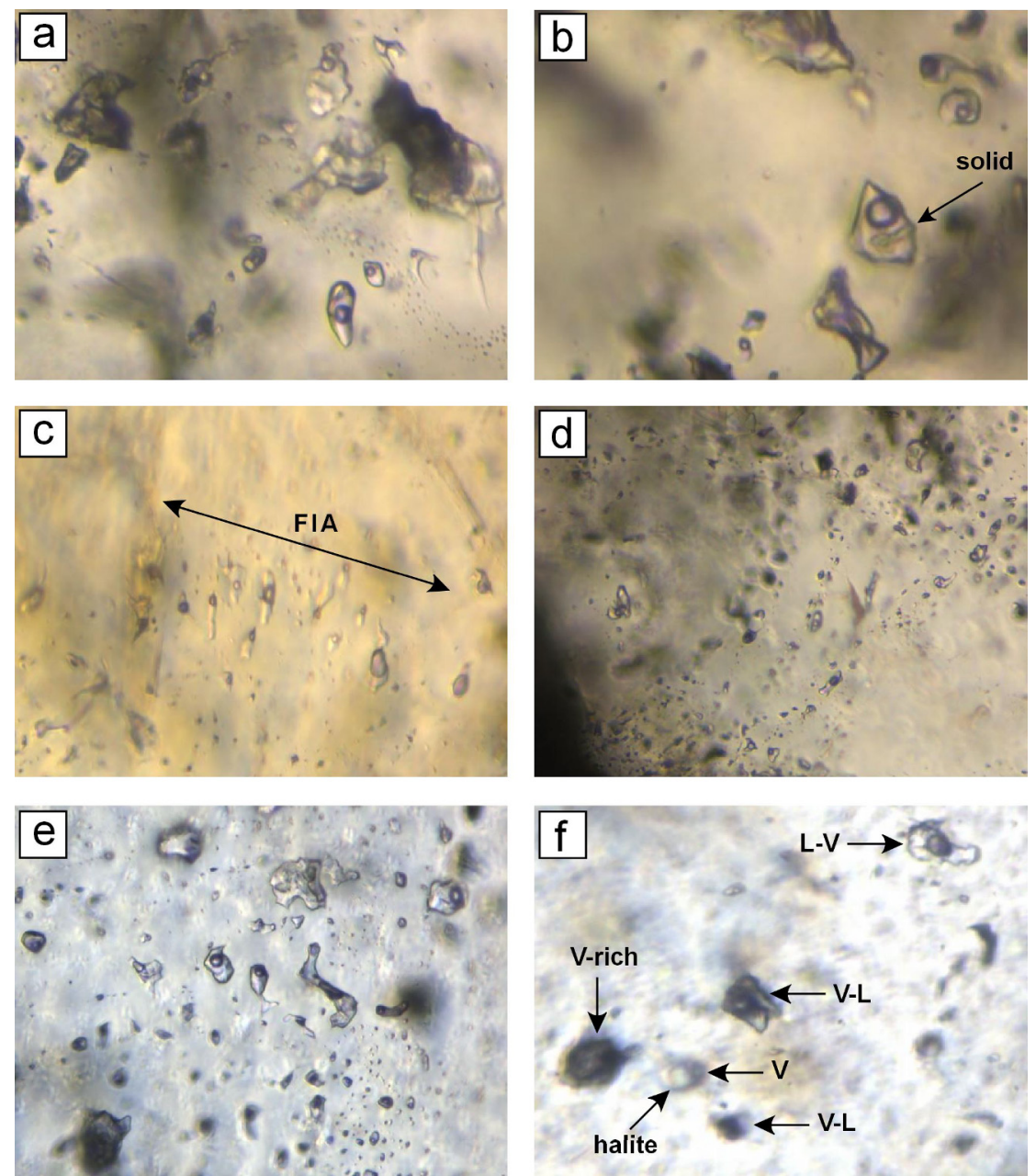

Figure 6. Representative fluid inclusions from Tesbihdere and Azitepe. Low Th L/V inclusions (Sample no: ATM-47, Azitepe sector), (b) Higher $T_{h}$ inclusions with accidentally trapped solids (Sample no: ATM-47, Azitepe sector), (c) Variable LV ratios within the same FIA (Sample no: TDG-24, Tesbihdere sector), (d) P or PS inclusion trails with constant L/V ratios (Sample no: ATM-47, Azıtepe sector), (e) Variable $\mathrm{L} / \mathrm{V}$ ratios in plane of inclusions (Sample no: TDG-24, Tesbihdere sector), (f) Boiling assemblage with L-V, V-L, V-rich and L-V-halite inclusions (Sample no: TDG-24, Tesbihdere sector).

trend for fluids from these two locations. Samples from Basmakci are more tightly constrained at lower salinities and their homogenization temperatures are lower than those of the other locations, so appear to form a discrete group although there is a some overlap of homogenization temperatures. There is no suggestion that these fluids represent an intermediate salinity third fluid, merely that the two fluids were perhaps better mixed and trapped at a lower temperature due to these veins being emplaced at a lower depth. Significantly more homogenization temperatures were measured and these are shown in the box and whisker plot (Figure 7) for the three locations.
The shaded box is the range for the $25^{\text {th }}$ and $75^{\text {th }}$ percentile and the median value, the other horizontal lines are the range for the 5 th and $95^{\text {th }}$ percentile. Values outside this range are shown as individual data points. There is no significant difference between the primary and secondary inclusions from the three deposits, but the range of $T_{h}$ values is smaller at Basmakci than Tesbihdere and Azitepe which also have a much higher median $T_{h}$ values as was previously mentioned. The majority of values from Tesbihdere and Azitepe are identical, the most obvious, but not significant, difference is the greater range of outlier $T_{h}$ values at Tesbihdere. 


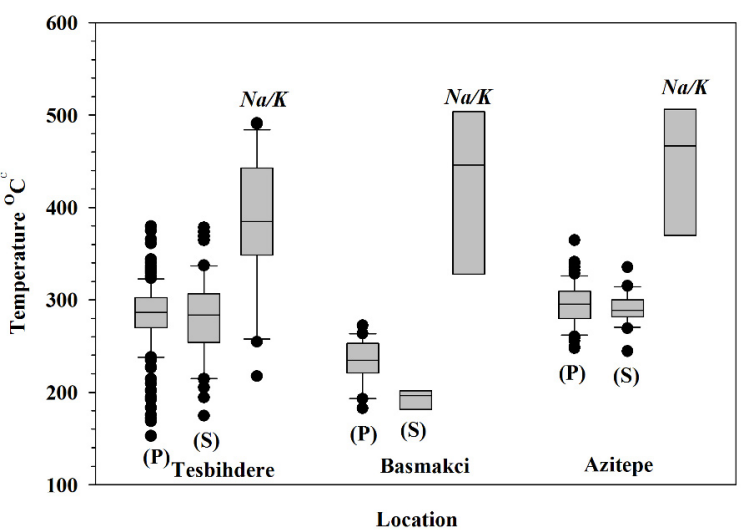

Figure 7. Box and whisker plot of the homogenization temperatures for $\mathrm{P}$ and $\mathrm{S}$ inclusions and calculated temperatures from LA-ICPMS Na/K ratios of individual inclusions. The boxes define the median value and the $25^{\text {th }}$ and $75^{\text {th }}$ percentiles, whiskers the $5^{\text {th }}$ and $95^{\text {th }}$ percentiles and individual data points that are outwith this range. There is no difference between $\mathrm{P}$ and $\mathrm{S}$ inclusions or between inclusions from Tesbihdere and Azitepe, inclusions from Basmakci are cooler. The calculated temperatures are significantly higher than the microthermometry $T_{h}$ values.

Table 2. Summary of the fluid inclusion microthermometry for quartzhosted inclusions from Tesbihdere, Basmakci and Azitepe.

\begin{tabular}{|c|c|c|c|c|c|c|c|c|}
\hline \multirow{2}{*}{ Sample } & \multirow{2}{*}{ Type } & \multirow{2}{*}{$\mathrm{Te}^{\circ} \mathrm{C}$} & \multicolumn{3}{|c|}{ Tm ice ${ }^{\circ} \mathrm{C}$} & \multicolumn{3}{|c|}{$\mathrm{Th}{ }^{\circ} \mathrm{C}$} \\
\hline & & & \multicolumn{6}{|c|}{ Min. Max. Average Min. Max. Average } \\
\hline \multicolumn{9}{|c|}{ Tesbihdere sector } \\
\hline \multirow[t]{2}{*}{ TDG-24A } & $\mathrm{P}$ & $-58 /-55$ & -6.2 & -1 & -4.2 & 238 & 331 & 284 \\
\hline & $\mathrm{S}$ & & - & - & - & 265 & 297 & 283 \\
\hline \multirow[t]{2}{*}{ TDG-24B } & $P$ & & -0.9 & -0.4 & -0.5 & 257 & 365 & 295 \\
\hline & $\mathrm{S}$ & & - & - & - & 275 & 321 & 296 \\
\hline \multirow[t]{2}{*}{ TDG-28 } & $\mathrm{P}$ & & -6.6 & -3.8 & -5.1 & 257 & 302 & 284 \\
\hline & $\mathrm{S}$ & & - & - & -3.1 & 252 & 284 & 266 \\
\hline \multirow[t]{2}{*}{ TDG-25 } & $P$ & & -3.2 & -2.9 & -3.0 & 152 & 332 & 267 \\
\hline & S & & & & -7.0 & 221 & 330 & 275 \\
\hline \multirow[t]{2}{*}{ TDG-36 } & $P$ & -56 & -201 & -0.3 & -1.1 & 183 & 316 & 236 \\
\hline & S & & - & - & - & 174 & 333 & 265 \\
\hline \multicolumn{9}{|c|}{ Basmakci sector } \\
\hline BSM-52 & $P$ & & -3.2 & -2.0 & -2.8 & 182 & 263 & 231 \\
\hline \multirow[t]{2}{*}{ BSM-54B } & $P$ & & -3.1 & -2.2 & -2.6 & 192 & 272 & 235 \\
\hline & $\mathrm{S}$ & & - & - & - & 178 & 202 & 193 \\
\hline \multicolumn{9}{|c|}{ Azitepe sector } \\
\hline \multirow[t]{3}{*}{ ATM-47 } & $P$ & -58 & -7.4 & -1.4 & -4.3 & 247 & 364 & 294 \\
\hline & PS & & - & - & -7.8 & 244 & 286 & 272 \\
\hline & $\mathrm{S}$ & & & & -3.6 & 269 & 335 & 295 \\
\hline
\end{tabular}

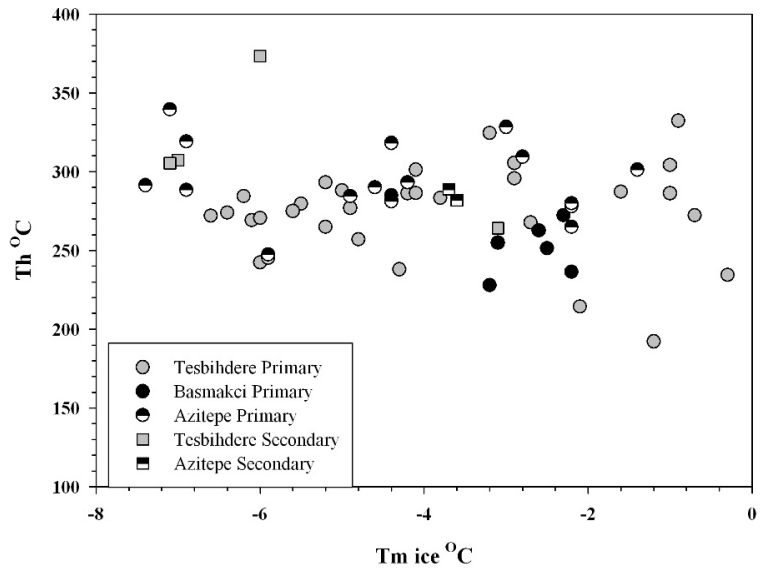

Figure 8. Homogenization and ice melting temperatures of primary and secondary inclusions from the 3 locations. The data define a dilution trend at approximately constant temperature and show there is no difference between $\mathrm{P}$ or $\mathrm{S}$ inclusions. Salinities from Basmakci are less variable and may appear to be cooler, but are not statistically different from the other samples.

\subsection{Crush-Leach Analyses}

Quartz samples from the 3 locations were analysed, but the quantity of salts released was extremely low, $\sim 5 \mathrm{ppm}$ TDS maximum, and only 3 samples from Tesbihdere provided results that are reliable. There is a big range in $\mathrm{Cl} / \mathrm{Br}(\mathrm{m})$ ratios from $\sim 2800$ to 15000 and $\mathrm{Na} / \mathrm{Br}(\mathrm{m})$ ratios from 2600 to $10000 . \mathrm{SO}_{4}$ was greater than the $\mathrm{Cl}$ concentration, but the presence of micron sized sulphide grains will have contaminated the analyses and so this data is unreliable. $\mathrm{Na} / \mathrm{Cl}(\mathrm{m})$ ratios were $\sim 0.7-$ 0.8 indicating the dominance of $\mathrm{Cl}$ as the major, but not exclusive anion in the fluids.

\subsection{LA-ICP-MS}

A summary of the results of the analyses of individual inclusions, or groups of very small inclusions, are presented in Table 3. as the means and standard deviations of the $\mathrm{wt} / \mathrm{wt}$ ratios relative to $\mathrm{Na}$ (internal standard element) for all the inclusions analysed in a particular sample. In general a minimum of $\sim 15$ inclusions or groups were ablated from each sample to ensure a representative analyses was obtained. The wt/wt ratios for individual inclusions are shown in Figure 9 and Figure 10. paired with other similar elements, alkali and alkaline earths and transition metals. There would appear to be similarities between samples from 
Tesbihdere, Azitepe and Basmakci and the mean values for a number of the key element/Na ratios were tested to determine if these were statistically similar. For this analysis both samples from Tesbihdere were combined as they come from the same mine gallery, but inclusions where we believe some accidentally trapped solids were ablated were removed from these tests (those samples where the $\mathrm{K} / \mathrm{Na}$ ratio was greater than 1$)$.

We applied a standard T-test (assuming unequal variances) to determine if, with a $95 \%$ degree of certainty, the mean values for the selected element/ $\mathrm{Na}$ ratios from the 3 localities were the same. The results show that the ratios of $\mathrm{Mg} / \mathrm{Na}, \mathrm{K} / \mathrm{Na}, \mathrm{Mn} / \mathrm{Na}$ and $\mathrm{Fe} / \mathrm{Na}$ from all 3 localities were the same and between Azitepe and Basmakci all the ratios were the same with a $95 \%$ certainty and in some cases $99 \%$ certainty. In some instances this criteria was not met; between Tesbihdere and Azitepe the $\mathrm{Cu} / \mathrm{Na}$ and $\mathrm{Pb} / \mathrm{Na}$ ratios were significantly different, between Tesbihdere and Basmakci the $\mathrm{Ca} / \mathrm{Na}, \mathrm{Zn} / \mathrm{Na}$ and $\mathrm{Pb} / \mathrm{Na}$ were significantly different. However, it is clear that there are enough similarities between the fluids from the three deposits to be confident that they represent the same mineralising fluid.

In Figure 9, the bivariate plot of wt/wt ratios show a group of analyses that have significantly higher $\mathrm{K} / \mathrm{Na}$ ratios, and possibly $\mathrm{Ca} / \mathrm{Na}$, that are due to the ablation of inclusions with accidently trapped solids. These solids were only observed in inclusions from Tesbihdere. The bivariate plots show no significant trends, except perhaps for $\mathrm{Ca} / \mathrm{Na}$ vs $\mathrm{K} / \mathrm{Na}$, other analyses from the three deposits all show a significant amount of overlap. The analyses of these mineralising fluids are $\mathrm{Na}>\mathrm{K}>\mathrm{Ca}>\mathrm{Mg}$ dominated with significant amounts of $\mathrm{K}$ and $\mathrm{Ca}$. Figure 10 , shows bivariate plots of the transition metal ratios that also indicate a large degree of overlap in the element ratios. The most significant observation is the difference between samples 24 and 28 from Tesbihdere (both of which come from the same mine gallery) in terms of $\mathrm{Zn}$ and $\mathrm{Pb}$. Sample 24 has distinctly higher $\mathrm{Zn}$ and lower $\mathrm{Pb}$ compared with sample 28 which is a closer match to the samples from Azitepe and Basmakci.

The actual elemental concentrations in the inclusions are shown in Table 3, using the most saline inclusions, as representative of the salinity of the mineralizing fluids, as the basis for this calculation. It was shown in Figure 8, that the salinity of the inclusions varies widely due to mixing of a high and low salinity fluid, but we believe the low salinity fluid is meteoric water that merely dilutes the mineralizing fluid but does not alter the element ratios. This is confirmed by the absence of any trends in the bivariate element plots whose spread in values is due to analytical uncertainties or excessively large ranges in individual element/ $\mathrm{Na}$ ratios. Therefore, knowing the actual salinity of all the inclusions that were ablated is not an obstacle to re-constructing the concentration of the cations in the fluid inclusions. The compositions of inclusions from Tesbihdere and Azitepe were calculated based on a salinity of $10 \mathrm{wt} . \% \mathrm{NaCl}$ equiv. and those from Basmakci based on a salinity of $6 \mathrm{wt} . \% \mathrm{NaCl}$ equiv. Based on the similarity between the inclusions from all three locations it is likely that the salinity at Basmakci was originally as high as the others but the vein quartz trapped a more discrete, diluted, inclusion population. $\mathrm{Na}$ is the dominant cation, $15,000-20,000 \mathrm{ppm}$, with the combined concentration of $\mathrm{Mg}, \mathrm{K}$ and $\mathrm{Ca}$ broadly equivalent to that of $\mathrm{Na}$. The concentration of Fe is low, $200-300$ ppm and only slightly higher than $\mathrm{Mn}$. Of particular interest are the main ore metals in the deposits, $\mathrm{Cu}, \mathrm{Zn}$ and $\mathrm{Pb}$, all of which have significant concentrations in the inclusion fluids. The $\mathrm{Cu}$ concentration is highest at $\sim 500 \mathrm{ppm}$ followed by $\mathrm{Zn}$ at $\sim 300-500 \mathrm{ppm}$ and $\mathrm{Pb}$ at $\sim 100$ 200 ppm. Despite the salinity at Basmakci being less than the other deposits, the $\mathrm{Pb}$ concentration at $\sim 500 \mathrm{ppm}$ is about twice that of the other deposits. The other elements are either close to or below the detection limit.

\subsection{S-Isotopes}

The $\delta^{34} \mathrm{~S}$ values of chalcopyrite in the Tesbihdere deposit range from -5.4 to $-2.4 \%$, in the Azitepe deposit from -5.6 to $-6.9 \%$ with galena from -9.0 to $-9.8 \%$ (Table 4$)$, and are more negative than the $\delta^{34} S$ values of sulphides from the majority of the magmatic hydrothermal deposits ( -3 to $+1 \%$; [37]). They are also lower than those of mantle $(0 \pm 3 \% 0)$, igneous rocks $(+1 \%$ oto $+3 \%$ ) sulphur [38], crustal sulphur (mean $+7 \%$; [39]) and sulphur derived from seawater $\left(+20 \%\right.$; [40]). Negative $\delta^{34} S$ sulphide values for low-sulphidation epithermal veins may have been be a consequence of interacting with an external, isotopically light S-source, such as biogenic sulphide minerals, however, no sedimentary sulphides were observed in any exposed sedimentary rocks in the area.

\section{Discussion}

\subsection{P-T conditions of mineralization}

The petrography of the fluid inclusions, their Th and salinity in the samples from the different locations indicates a consistency between different fluid events. There are also different periods of quartz growth at the different locations and where we have measured inclusions from these, the data are the same.

Inclusions within the same FIA or spatially close to 


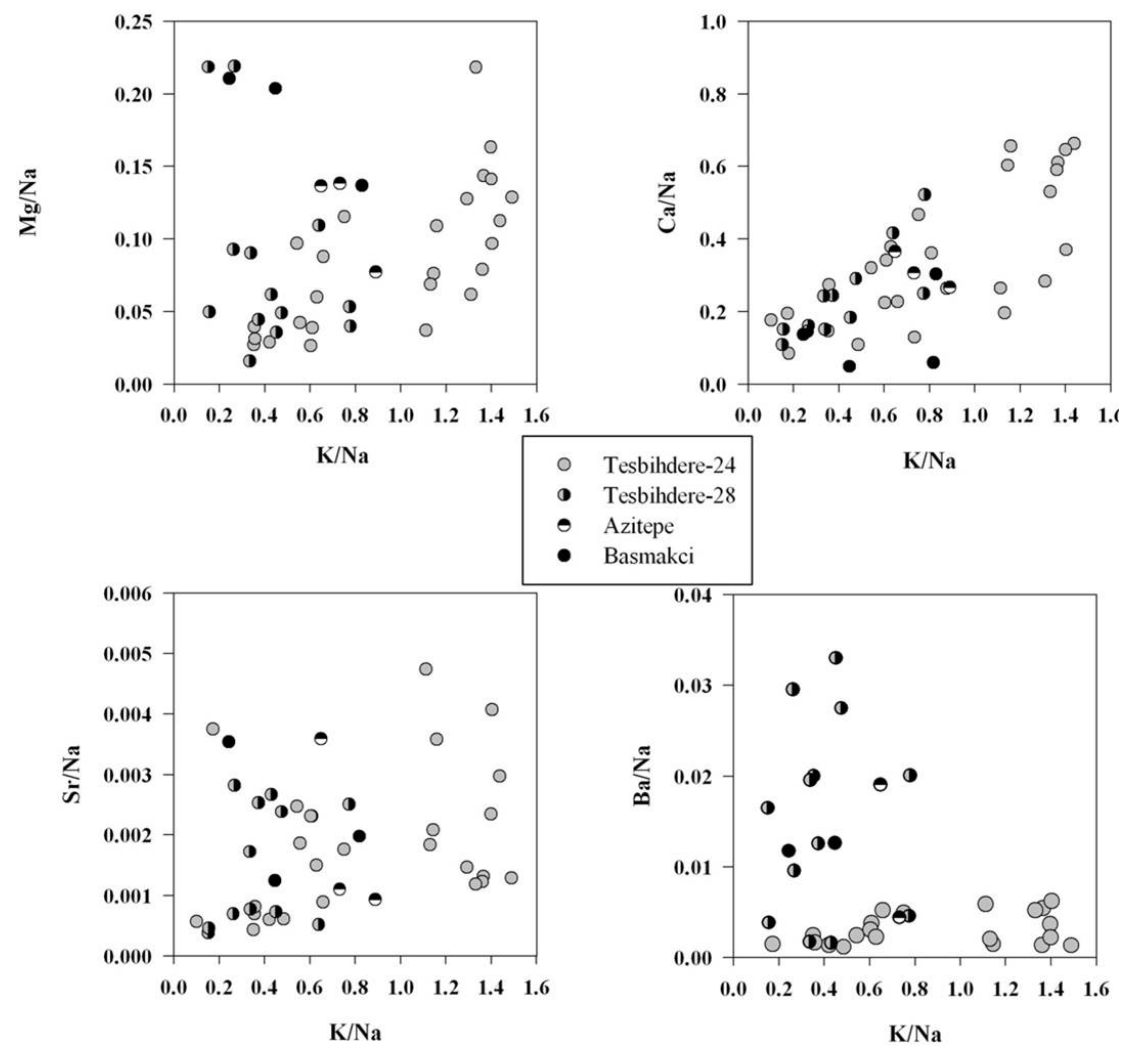

Figure 9. Bivariate plots of the wt./wt. ratios for alkali and alkaline earth elements determined by LA-ICPMS from individual fluid inclusions. In all the diagrams there are a distinct group of high $\mathrm{K} / \mathrm{Na}$ ratios that are probably due to ablation of trapped solids. The data from different deposits are not statistically different except that one sample from Tesbihdere (24) has a lower Ba/Na ratio. There is also a positive correlation between $\mathrm{Ca} / \mathrm{Na}$ and $\mathrm{K} / \mathrm{Na}$ that includes the distinctly high $\mathrm{K} / \mathrm{Na}$ values and may be due to trapping of variable amounts of solids. The lowest $\mathrm{K} / \mathrm{Na}$ values would give temperatures consistent with those from microthermometry.

each other (Figure 6(a)-(f)) would have been trapped at more or less the same time, but they have different L/V ratios and different Th values. There has clearly been dilution through mixing of a moderately saline fluid with presumably very low salinity meteoric water and this occurred at almost constant temperature. $\delta \mathrm{D}$ and $\delta^{18} \mathrm{O}$ of fluid inclusions and quartz [6] supports mixing of local meteoric water and magmatic fluids. Boiling in a gaspoor system is an alternative explanation but we have insufficient evidence to support this.

In general the fluid inclusions do not show the classic evidence of boiling, although there are rare examples of a boiling assemblage and variable $\mathrm{L} / \mathrm{V}$ ratios or $\mathrm{V}$ rich inclusions within the same assemblage (Figure 6(c), (f)). However, it appears that the confining pressure must always have been sufficient to prevent boiling. Considering inclusions from Tesbihdere and Azitepe, which have very similar average and $\pm 2 \sigma \quad T_{h}$ as shown in Figure 11, the highest temperature inclusions would require to have been trapped at greater than $2000 \mathrm{~m}$ to prevent boiling, whereas the lower temperature fluid would only require $400 \mathrm{~m}$ in a hydrostatic pressure regime. Similarly for the inclusions from Basmakci the highest temperatures require some $700 \mathrm{~m}$ and the lower temperature inclusions some $100 \mathrm{~m}$ of hydrostatic pressure to prevent boiling. Trapping at such variable depths, in a hydrostatic regime, would imply the hotter fluids were trapped first and then the cooler fluids trapped as erosion reduced the depth of burial. This does not fit with the observed petrography or the reconstructed stratigraphic depth. The veins sampled at Tesbihdere are currently approximately $100 \mathrm{~m}$ from the surface and Azitepe are surface samples, so at least $2000 \mathrm{~m}$ would need to have been lost from the top of the deposit by erosion. At Basmakci these are again surface samples and would require a loss of $700 \mathrm{~m}$ through erosion, but this 

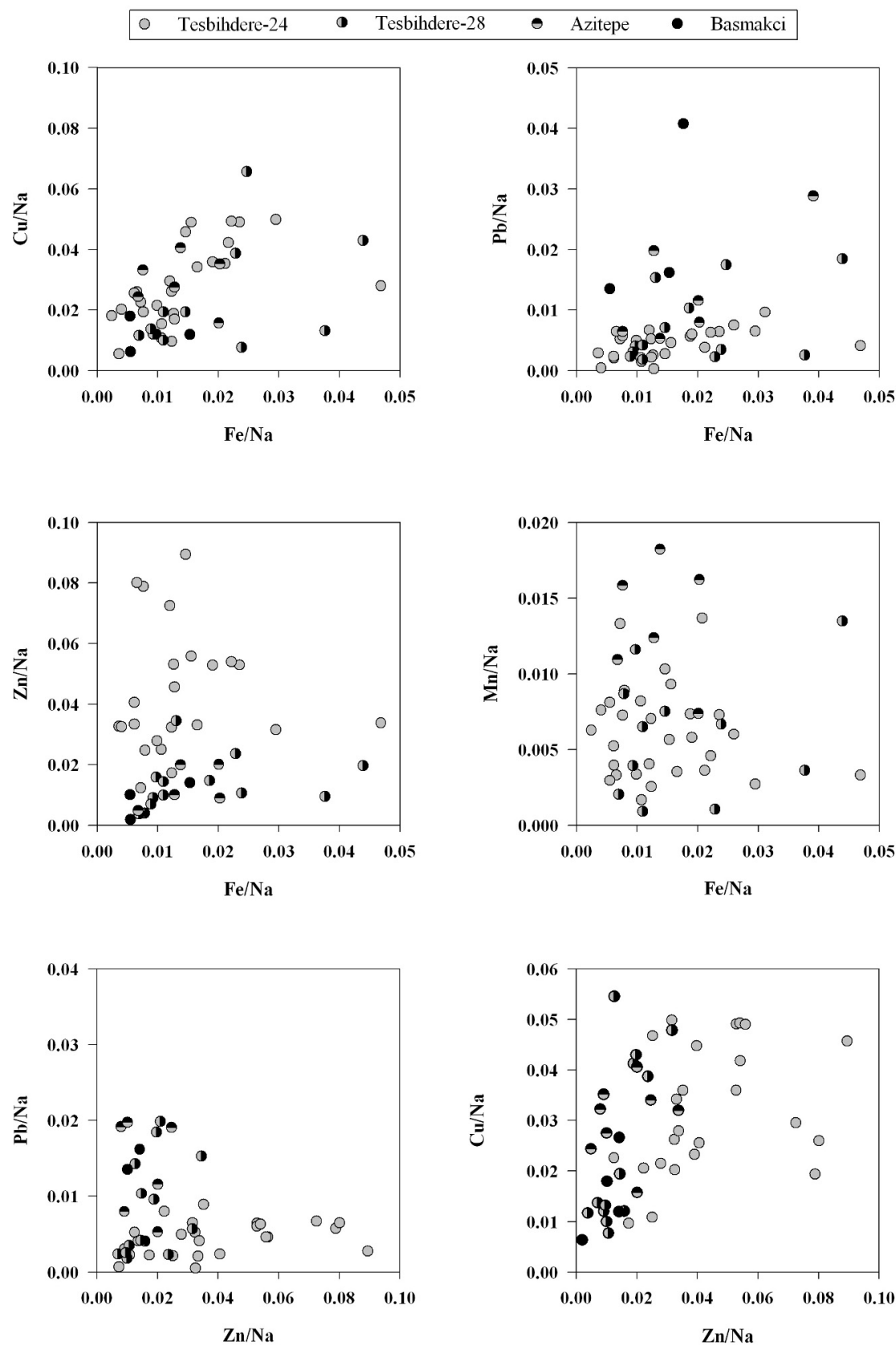

Figure 10. Bivariate plots of the wt./wt. metal ratios for individual fluid inclusions determined by LA-ICPMS. The statistical significant comparisons between the different localities are discussed in the text. In general there is no significant difference, except that Tesbihdere-24 has significantly higher $\mathrm{Zn}$ and lower $\mathrm{Pb}$ than other locations. There is a reasonable positive correlation between increasing $\mathrm{Cu}$ and Fe and $\mathrm{Zn}$.

might be more attainable. Alternatively hotter fluids may have ascended from depth and undergone rapid conductive cooling at shallower levels, but this is unlikely.
Therefore, the most likely explanation for the large variation in $T_{h}$ values is a change in the confining pressure from lithostatic, or close to lithostatic, to a hydostatic 
Table 3. LA-ICP-MS analyses of individual fluid inclusions: Average elemental ratios (wt/wt relative to $\mathrm{Na}$ ) and concentrations in ppm.

\begin{tabular}{|c|c|c|c|c|c|c|c|c|c|c|c|c|c|c|c|c|}
\hline Sample & Salinity & & $\mathrm{Na}$ & $\mathrm{Mg}$ & $\mathrm{K}$ & $\mathrm{Ca}$ & Mn & $\mathrm{Fe}$ & $\mathrm{Cu}$ & $\mathrm{Zn}$ & As & $\mathrm{Rb}$ & $\mathrm{Sr}$ & $\mathrm{Ag}$ & $\mathrm{Ba}$ & $\mathrm{Pb}$ \\
\hline \multicolumn{17}{|c|}{ Tesbihdere sector } \\
\hline & & Average & 1 & 0.0816 & 0.8343 & 0.4022 & ¡0.005 & 0.0163 & 0.0326 & 0.0348 & ¡0.0078 & ¡0.0042 & 0.0025 & 5 ¡0.0004 & 0.0039 & 0.0044 \\
\hline \multirow[t]{3}{*}{ TDG-24A } & 10 & Std Dev & & 0.047 & 0.440 & 0.183 & 0.002 & 0.011 & 0.015 & 0.014 & 0.005 & 0.002 & 0.001 & 0.0003 & 0.003 & 0.002 \\
\hline & & ppm & 16195 & 1322 & 13511 & 6514 & ¡81 & 259 & 528 & 564 & ¡126 & ¡68 & 40 & ¡6 & 63 & 71 \\
\hline & & Average & 1 & 0.0827 & 0.4126 & 0.2625 & 0.007 & 0.0167 & 0.0273 & 0.0157 & 0.0062 & $¡ 0.0039$ & 0.0022 & 0.0002 & 0.0179 & 0.0092 \\
\hline \multirow[t]{2}{*}{ TDG-28 } & 10 & Std Dev & & 0.056 & 0.199 & 0.108 & 0.005 & 0.011 & 0.019 & 0.009 & 0.004 & 0.003 & 0.001 & 0.0001 & 0.011 & 0.007 \\
\hline & & $\mathrm{ppm}$ & 21109 & 1746 & 8710 & 5541 & 148 & 353 & 576 & 331 & 131 & ¡2 & 46 & 4 & 378 & 194 \\
\hline \multicolumn{17}{|c|}{ Azitepe sector } \\
\hline & & Average & 1 & 0.1174 & 0.6290 & 0.2529 & 0.0125 & 0.0146 & 0.0254 & 0.0148 & ¡0.0127 & ¡0.0149 & 0.0024 & + ¡ 0.0006 & 0.0135 & 0.0143 \\
\hline \multirow[t]{2}{*}{ ATM-47 } & 10 & Std Dev & & 0.066 & 0.243 & 0.100 & 0.007 & 0.010 & 0.011 & 0.009 & 0.005 & 0.007 & 0.001 & 0.0003 & 0.006 & 0.007 \\
\hline & & ppm & 18517 & 2174 & 11647 & 4863 & 231 & 270 & 470 & 274 & ¡235 & ¡276 & 44 & ¡11 & 250 & 265 \\
\hline \multicolumn{17}{|c|}{ Basmakci sector } \\
\hline & & Average & 1 & 0.1444 & 0.5837 & 0.1895 & 0.007 & 0.0109 & 0.0157 & 0.0100 & ¡ 0.0148 & ¡0.0089 & 0.0022 & 2 ¡ 0.0025 & 50.0121 & 0.0319 \\
\hline \multirow[t]{2}{*}{ BSM-54B } & 6 & Std Dev & & 0.085 & 0.288 & 0.123 & 0.004 & 0.006 & 0.008 & 0.006 & 0.013 & 0.004 & 0.001 & 0.002 & 0.0006 & 0.021 \\
\hline & & $\mathrm{ppm}$ & 15308 & 2204 & 8940 & 2893 & 107 & 167 & 240 & 156 & ¡230 & ¡138 & 31 & ¡58 & 184 & 488 \\
\hline
\end{tabular}

Table 4. Sulfur isotope composition, geothermometric temperature $\left({ }^{\circ} \mathrm{C}\right)$ and $\delta^{34} \mathrm{~S}$ values of $\mathrm{H}_{2} \mathrm{~S}$ in equilibrium with chalcopyrite and galena from the Tesbihdere deposit.

\begin{tabular}{|c|c|c|c|c|c|c|c|}
\hline \multirow{2}{*}{ Sample } & \multirow{2}{*}{$\begin{array}{l}\text { Location } \\
\text { (Sector) }\end{array}$} & \multirow{2}{*}{$\begin{array}{c}\delta^{34} S \\
\text { values of } \\
\text { chalcopyrite }\end{array}$} & \multirow{2}{*}{$\begin{array}{c}\delta^{34} \mathrm{~S} \\
\text { values of } \\
\text { galena }\end{array}$} & \multirow{2}{*}{$\begin{array}{l}\text { Sulphur isotope } \\
\text { geothermometric } \\
\text { temperature }\left({ }^{\circ} \mathrm{C}\right)\end{array}$} & \multirow{2}{*}{$\begin{array}{l}\text { Fluid inclusion } \\
\text { microthermometric } \\
\text { temperature }\left({ }^{\circ} \mathrm{C}\right)\end{array}$} & \multicolumn{2}{|c|}{$\delta^{34} \mathrm{~S}$ values of $\mathrm{H}_{2} \mathrm{~S}$} \\
\hline & & & & & & Chalcop & Galena \\
\hline TD-24 & Tesbihdere & -3.6 & - & - & 290 & -3.8 & - \\
\hline TD-25 & Tesbihdere & -3.6 & - & - & $273^{* * *}$ & -3.8 & - \\
\hline TD-30 & Tesbihdere & -5.4 & - & - & $273^{* * *}$ & -5.6 & - \\
\hline TD-35 & Tesbihdere & -2.4 & - & - & 265 & -2.4 & - \\
\hline TD-38 & Azitepe & -5.6 & -9.0 & $177^{*}$ & $294^{* * * * *}$ & -5.8 & -7.0 \\
\hline TD-49 & Azitepe & -6.9 & -9.6 & $232^{*}$ & $294^{* * * * *}$ & -7.1 & -7.6 \\
\hline TD-50 & Azitepe & - & -9.8 & - & $294^{* * * * *}$ & - & -7.8 \\
\hline TD-110 & Azitepe & - & -9.3 & - & $294^{* * * * *}$ & - & -7.3 \\
\hline
\end{tabular}

(*) Calculated using the related equation suggested by [57]

$\left.{ }^{* * *}\right)$ Temperature values represent average for analyzed samples from Tesbihdere sector

${ }^{(* * *)}$ Temperature values represent average for analyzed samples from Azıtepe sector

regime as the vein and fracture systems opened. The pressure change would result in adiabatic expansion of the fluid and loss of temperature. In Figure 11, the mean $\pm 2 \sigma$ in the $T_{h}$ values for each deposit are shown. This range was chosen to exclude potentially erroneously high and low values and to give a more realistic $T_{h}$ range for the different deposits. Tesbihdere and Azitepe are evaluated together as the $T_{h}$ range is almost identical. Plotting the upper and lower values for $T_{h}$ on the $L-V$ curve and determining the confining pressure instead of depth required to prevent boiling, the high $T_{h}$ inclusions would require a minimum of $\sim 130$ bars and the lower Th inclusions a minimum of $\sim 38$ bars. Assuming the high pressure is lithostatic this equates to a minimum depth of burial of $\sim 500 \mathrm{~m}$. Altering the pressure to hydrostatic at the same depth gives a minimum pressure of $\sim 40$ bars which is identical to the pressure required to prevent boiling of the low Th fluid inclusions (Figure 11, inset). 


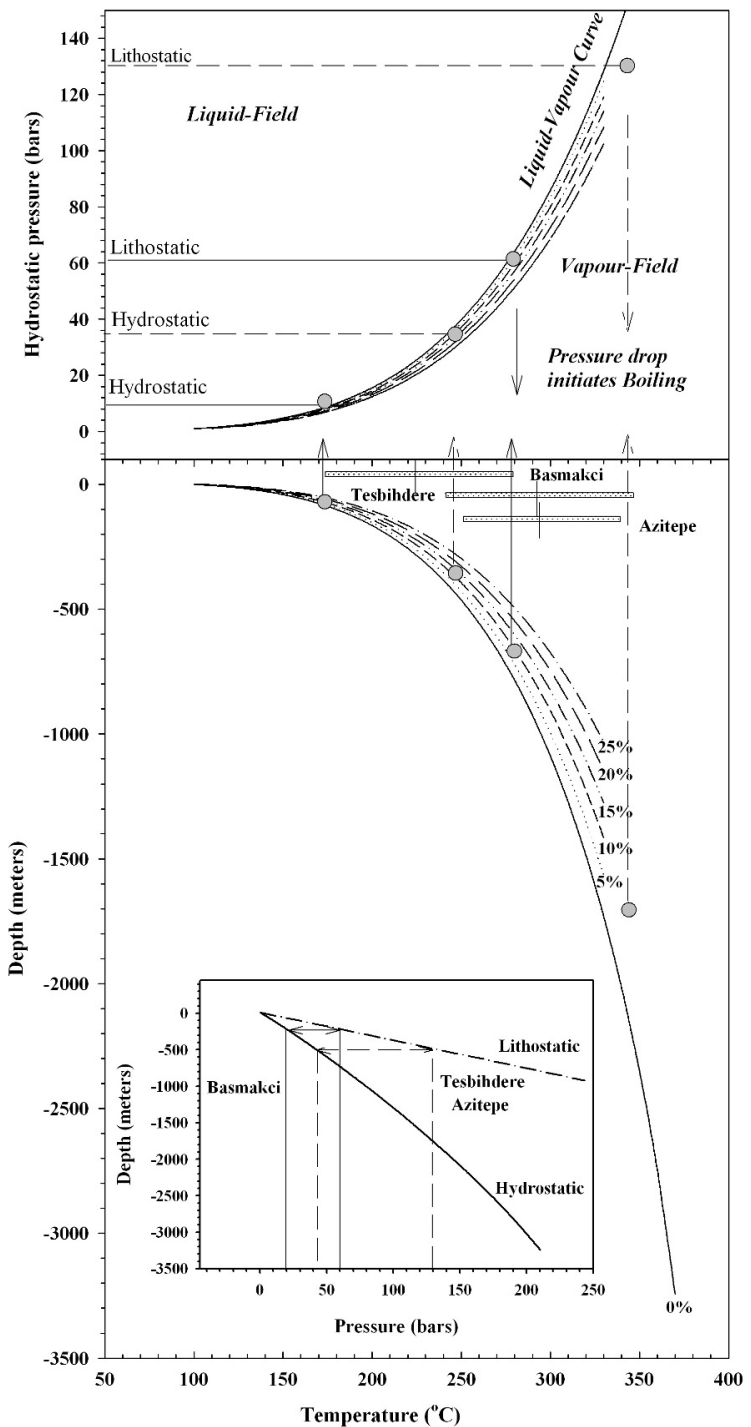

Figure 11. Pressure-Temperature-Depth plot (drawn from data in [56]). The mean and $95 \%$ confidence range of homogenization temperatures are shown for each deposit and plotted on to the boiling curve for the appropriate salinity to illustrate the minimum depth required to prevent boiling. We infer the fluids with high Th values are close to lithostatic pressure and lowest Th values close to hydrostatic pressure. The pressures required to prevent boiling are determined and shown vs the depth against the lithostatic and hydrostatic pressure gradients (inset). These match exactly for emplacement depths of $\sim 500 \mathrm{~m}$ (Tesbihdere and Azitepe) and $\sim 200$ $300 \mathrm{~m}$ for Basmakci.
The same procedure can be applied to the inclusions from Basmakci and again the pressure difference going for a lithostatic confining pressure to hydrostatic matches the minimum required along the $\mathrm{L}-\mathrm{V}$ boiling curve, although at a shallower depth of $\sim 200-300 \mathrm{~m}$.

However, it is unclear how the decrease in pressure is achieved during vein opening. If the vein opens at lithostatic pressure along the $L-V$ boiling curve then the resultant pressure drop to a hydrostatic pressure moves the fluids from the $L-V$ curve into the $V$-field and the fluid boils until the temperature decreases and the $L-V$ curve is again reached. The vast majority of inclusions do not show evidence of boiling which is only rarely observed. It is possible that as these are near surface veins the evidence of boiling is lost during vein opening. Alternatively we may have a scenario where the vein opening and pressure decrease is gradual and the fluids cool along or close to the L-V boiling curve and therefore there would be very little boiling in any case. In Figure 11, the pressure differential between lithostatic and hydrostatic should push fluids from all three locations into the $V$-field and boiling should exist, but is largely absent from all three deposits.

The deposits of Tesbihdere, Azitepe and Basmakci have characteristics in common with many other epithermal deposits in western Turkey, such as Kartaldag and Madendag [16], Bergama [41], Koru [6, 7] and a compilation of deposits by [42]. Of direct relevance to this study is the work of [15] on the Sahlinli (their regional name which includes the mineralization at Azitepe, Basmakci and Ulu Dere) and Tesbihdere deposits with which we can compare our data. Their fluid inclusion study reports results for $T_{h}$, salinity with the range of values that are essentially identical to this study. They did not find any evidence of boiling but clearly there was a distinct variation in the $L / V$ ratio of the inclusions reflected by a variation in $T_{h}$ between 220 and $320^{\circ} \mathrm{C}$. Individual samples have a more restricted $T_{h}$ range when the number of measurements is small, but is much larger as the number of measurements made in each sample increases. Salinity varies between 9 and 0.5 wt.\% $\mathrm{NaCl}$ equiv. with a large range in individual samples. Their interpretation is of two fluid pulses, firstly cooling from 320 to $260^{\circ} \mathrm{C}$ followed by a 260 to $220^{\circ} \mathrm{C}$ fluid that was responsible for the introduction of base-metals $\mathrm{Au}$ and $\mathrm{Ag}$. The salinity range of both fluids is essentially the same, $\sim 9$ to 0.5 wt.\% $\mathrm{NaCl}$ equiv. Their bimodal temperature distribution does not exist and is largely a function of low numbers of measurements and although they suggest a cooling and dilution evolution of the magmatic fluid this is also not entirely supported by the data. Statistical analysis of the data from the different samples or between inclusions 
hosted in quartz or sphalerite shows they are from the same population and there is no significant difference. They infer a depth of emplacement of 800 to $1100 \mathrm{~m}$ based on reconstruction of the volcanic overburden and this would provide enough pressure to prevent the fluids boiling when the veins open and the pressure regime changes to hydrostatic. However the pressure differential between lithostatic and hydrostatic does not allow the fluids to cool by adiabatic expansion over the range they have measured, the minimum temperature possible would be $\sim 270^{\circ} \mathrm{C}$, but temperatures as low as $220^{\circ} \mathrm{C}$ have been measured. Cooling and dilution to the lower temperature and salinities during their $2^{\text {nd }}$ fluid pulse would be difficult/unlikely because this would mean forcing meteoric water against a supra-hydrostatic pressure. If the data were interpreted as we have done then the high and low temperature range is easily achieved by going from lithostatic to hydrostatic pressure at depth similar to those we calculate for Tesbihdere, Azitepe and Basmakci, approximately $500 \mathrm{~m}$ and $200-300 \mathrm{~m}$ respectively.

\subsection{Fluid composition}

The small number of low eutectic melting temperatures indicates the fluid inclusions contained a significant amount of cations, most likely $\mathrm{Ca}$, in addition to $\mathrm{NaCl}$ in the fluid. This data agrees with the fluid inclusions results from the nearby deposit of Koru [6] that [15] claimed were in error, because they did not observe low eutectic values, instead measuring higher eutectic temperatures of $\sim-28^{\circ} \mathrm{C}$ (not the $-24^{\circ} \mathrm{C}$ to $-19^{\circ} \mathrm{C}$ they report) that they suggest is indicative of a dominantly $\mathrm{H}_{2} \mathrm{O}$ $\mathrm{NaCl}$ fluid. Observation of eutectic melting is difficult to observe in low salinity inclusions, but in their photograph of eutectic melting at $-24^{\circ} \mathrm{C}$ there is clearly significant melting prior to this temperature which in the $\mathrm{H}_{2} \mathrm{O}-\mathrm{NaCl}$ system indicates the presence of significant amounts of other cations (at least $\mathrm{KCl}$ ) in addition to $\mathrm{NaCl}$ in the fluids. This is confirmed by our LA-ICPMS analyses of the inclusions (Table 3, Figure 9) where K/Na wt/wt ratios vary between $\sim 0.4$ to 0.8 and $\mathrm{Ca} / \mathrm{Na}$ wt/wt ratios vary between $\sim 0.2$ to 0.4 which is sufficient to be observed as eutectic melting temperatures of $\sim-56^{\circ} \mathrm{C}$.

Excluding the $\mathrm{K} / \mathrm{Na}$ wt/wt ratios of over 1, which we believe is due to ablation of trapped solids, there is a considerable range of values from $\sim 0.2$ to 0.9 with the majority around 0.4 to 0.8 . Applying a mineralfluid geothermometer [43] the calculated temperatures are significantly higher than the fluid inclusion Th values as seen in Figure 7. Only the lowest $\mathrm{K} / \mathrm{Na}$ ratios yield temperatures that are similar to the highest fluid inclusion Th values. The elevated $K$ concentrations could be due to less obvious solids being trapped and there does appear to be a correlation with $\mathrm{Ca}$ in the fluids. However, high $K$ concentrations are possible in acidsulphate fluids which are present at shallow levels in epithermal systems. The shallow depths indicated by our P-T calculations would support this. We do not believe the high temperatures from the $\mathrm{Na} / \mathrm{K}$ geothermometer represent fluid-rock equilibration at these temperatures as this would require these to have been generated at several kilometres depth and then ascend to shallow levels without boiling or re-equilibration along the flow path.

The ore metal concentrations of the fluids are consistent with crustal fluids at these temperatures and salinities [44]. The $\mathrm{Cu}$ concentration is between $\sim 250$ and $550 \mathrm{ppm}, \mathrm{Zn}$ between 150 and $550 \mathrm{ppm}$ and $\mathrm{Pb}$ between $\sim 70$ and $500 \mathrm{ppm}$. However, in comparison to other magmatically derived fluids the metal contents in these fluids are significantly lower [45, 46]. This is due to the lower salinity, lower temperature and hence the reduced ability of the metals to be transported as chloride complexes. The statistical analysis (based on the element/ $\mathrm{Na}$ ratios) showed there to be significant differences (at a 95\% confidence level) between Tesbihdere and Azitepe for $\mathrm{Cu}$ and $\mathrm{Pb}$ and between Tesbihdere and Basmakci for $\mathrm{Zn}$ and $\mathrm{Pb}$. Otherwise there were no statistical differences between the other metals at the different deposits. There is also a clear difference in the $\mathrm{Zn}$ concentrations for the two Tesbihdere samples, from the same gallery. Deposition of the ore metals from chloride complexes would be by cooling of the fluids due to adiabatic expansion on opening of the veins and or dilution of the chloride complexs by meteoric water. The destabilisation of Au-bisulphide complexes producing $\mathrm{H}_{2} \mathrm{~S}$ would also be important.

\subsection{Source of Sulphur}

The $\delta^{34} \mathrm{~S}$ values of chalcopyrite from the Tesbihdere deposit, range from -5.4 to $-2.4 \%$ and are slightly more negative than the $\delta^{34} \mathrm{~S}$ values of sulfides from the majority of magmatic hydrothermal deposits $(-3$ to $+1 \%$; [37]). The more negative $\delta^{34} \mathrm{~S}$ sulfide values for low-sulphidation epithermal veins might be a consequence of the ore fluid interacting with an external, isotopically negative $\mathrm{S}$ source, such as biogenic sulfide minerals. However, no sedimentary sulfide minerals were observed in any exposed country rocks in the Tesbihdere deposit. These more negative $\delta^{34} S$ values can be explained if there was boiling of the hydrothermal fluid as we suggest at the Tesbihdere deposit. It has been suggested [47] that fluid boiling will lead to a loss of $\mathrm{H}_{2}$ and the oxidation of the ore fluid, and in a more oxidized ore fluid, the ratio of 
$\mathrm{H}_{2} \mathrm{~S} / \mathrm{SO}_{4}^{2-}$ will decrease dramatically, leading more ${ }^{34} \mathrm{~S}$ to be concentrated in $\mathrm{SO}_{4}^{2-}$, resulting in the observed more negative $\delta^{34} \mathrm{~S}$ values in sulphides (e.g., $[48,49]$ ).

Such negative $\delta^{34} S$ values are not unique and this process has been proposed for the sulphides at the Valles Caldera, Summitville and White Island [50-52]. It was suggested [47] that fluid boiling will lead to a loss of $\mathrm{H}_{2}$ which occurs faster than the loss of $\mathrm{H}_{2} \mathrm{~S}$ from the aqueous fluid into the vapour phase [53]. Oxidation of aqueous $\mathrm{H}_{2} \mathrm{~S}$ would occur leading to preferential incorporation of ${ }^{34} \mathrm{~S}$ into $\mathrm{SO}_{2}$ or $\mathrm{SO}_{4}^{2-}$, for example, with the $\mathrm{H}_{2} \mathrm{~S}$ remaining in the fluid becoming lighter as boiling progresses and thereby negative $\delta^{34} \mathrm{~S}$ values in sulphides (e.g., $[48,49]$ ). At White Island [52] the disproportionation of $\mathrm{SO}_{2}$ leads to large $\mathrm{SO}_{4} / \mathrm{H}_{2} \mathrm{~S}$ ratios and an oxidised acidic solution (acid-sulphate zone).

Our data for suphide minerals from Tesbihdere and Azitepe (overall $\delta^{34} \mathrm{~S}-2.4$ to $-9.8 \%$ ) are consistent with the data of [14] for Sahinli and Tespihdere where for chalcopyrite $\left(\delta^{34} S-0.1\right.$ to $\left.-5.3 \%\right)$, pyrite $\left(\delta^{34} S-0.5\right.$ to $4.5 \% 0)$, Sphalerite $\left(\delta^{34} S-3.6\right.$ to $\left.-6.8 \%\right)$ and galena $\left(\delta^{34} S\right.$ -3.7 to $-6.5 \%$ ). However, their interpretation of sulphur from either igneous rock or local wallrocks would seem to be unlikely and rule out the derivation of sulphur from the magma driving the mineralization. Our conclusions are that sulphur was indeed derived from the magmatic fluid and that boiling with changes in the redox state of the fluid was responsible for the distinctly negative $\delta^{34} S$ values. This process is observed in other deposits worldwide and fits with our fluid inclusion data and the high $K$ content of the fluids which are frequently found in acid-sulphate environments.

Other deposits in the Biga Peninsula (Figure 12) also have distinctly negative $\delta^{34} \mathrm{~S}$ values; sphalerite and galena from the Koru deposit $\left(\delta^{34} S-0.1\right.$ to $-5.2 \%$; [29]) and galena, sphalerite and chalcopyrite from the Arapucandere deposit ( $\delta^{34} S-0.9$ to $-5.9 \%$; [13]). We suggest that these may also be indicative of boiling and more oxidising conditions in the ore fluids over this general area when other evidence such as fluid inclusions or mineral assemblages may have been lost. However, we do not currently have enough evidence to suggest the samples we have investigated are the major zones of boiling but further studies could indicate a causative link between zones of negative $\delta^{34} S$ and high gold grades.

\section{Conclusions}

The use of fluid inclusions can be an effective means of understanding the fluids in epithermal deposits and how they relate to their parental magmatic systems.

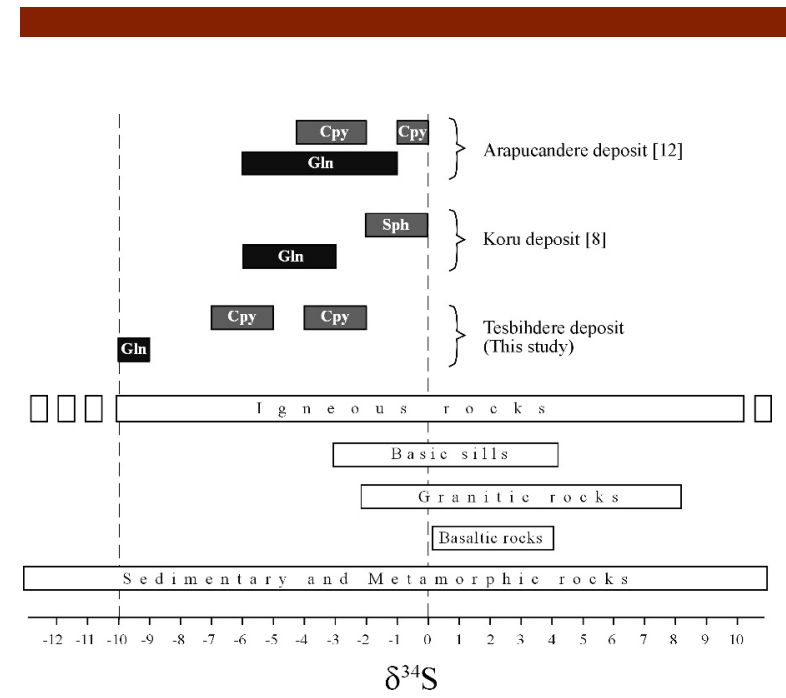

Figure 12. Sulfur isotope distributions for galena, chalcopyrite and sphalerite in Tesbihdere deposit. Isotopic distributions of different deposits and rock units were also added for comparison. Rock unit composition bars were taken from [37].

The Biga Peninsula and western Turkey in general contain many epithermal deposits whose characteristics are similar to the mineralization at Tesbihdere, Azitepe and Basmacki studied here. Many of these deposits have had fluid inclusion research that show a similarity in the salinity and temperature of the mineralization. These are what might be expected from the general model and vertical structure for this type of mineralization and other deposits worldwide. Stable isotopes of the inclusions and host quartz $\left(\delta \mathrm{D}, \delta^{18} \mathrm{O}\right)$ not unexpectedly show different degrees of mixing between meteoric and magmatic water. However, there is a general lack of clarity of the fluid processes during mineralization and no information on the composition and especially the metal concentration of the fluids.

This study has concentrated on those parameters, fluid processes and fluid composition to better understand the how the metals were transported and ores deposited. The compilation of [44] showed that the composition of crustal fluids are strongly rock buffered and the only real independent variables affecting metal concentrations are temperature and chlorinity (salinity). Metals are transported as chloride complexes and increasing temperature and/or salinity enhances metal solubility. Decreasing either/both of these substantially reduces the fluids ability to maintain metal in solution and deposition occurs. In the veins studied we see a reduction in salinity from $\sim 10$ to 1 wt.\% $\mathrm{NaCl}$ equiv and temperature decreases of around $150^{\circ} \mathrm{C}$ in inclusions over $10^{\prime} \mathrm{s}$ of 
micron distances. The veins are acting as regions of heterogeneous fluid mixing between magmatic derived, higher salinity, fluid and meteoric water. This occurs over a very limited temperature range and there is no evidence of cooling caused by dilution as [15] propose. We suggest the transition from near lithostatic to hydrostatic pressure was gradual in the samples studied, so that boiling may not have been a significant occurrence, but we cannot rule out that evidence of more extensive boiling was lost in this shallow environment. However, the change from lithostatic to hydrostatic pressure on opening of the veins is sufficient to produce the wide range of homogenization temperatures due to loss of heat from the fluid by adiabatic expansion. Based on our P-T calculations we can show the veins at Tesbihdere and Azitepe were emplaced about $500 \mathrm{~m}$ beneath the surface and at Basmakci about 200-300 m and not at around $1000 \mathrm{~m}$ as [15] suggest.

For the first time the metal concentrations and the composition of the fluids has been revealed by LA-ICPMS. The high $K$ concentrations are well in excess of what would be expected from equilibrium at the homogenization temperatures. This, we suggest, is due to high sulphate in the fluids as in geothermal regions acid-sulphate fluids have excessive $\mathrm{K}$ and the apparent correlation with increasing Ca points to the destruction of feldspars. As we are suggesting shallow emplacement depths, typical of the acid-sulphate zone, for the fluids this would be a reasonable interpretation. The low $\mathrm{Fe} / \mathrm{Me}$ ratios are also indicative of a more oxidising fluid [54]. There are also a significant amount of open space textures at Basmakci which would be consistent with a shallow depth. The concentrations of ore metals, $\mathrm{Cu}, \mathrm{Zn}$ and $\mathrm{Pb}$, are at concentrations of 100's of ppm and within the range shown for this salinity and temperature by [44] making them effective mineralizing fluids capable of depositimg substantial amounts of metal on cooling and dilution.

Boiling is the most effective means of depositing Au from the fluids, but we have no clearly definitive evidence of extensive boiling based on the fluid inclusions. We have indications that it has occurred from one example of a typical boiling assemblage and quite variable $\mathrm{L} / \mathrm{V}$ ratios within FIA's. We did not detect any Au in these fluids but as $\mathrm{Au}$ and $\mathrm{Ag}$ are often found as electrum in these deposits we can use our measured $\mathrm{Ag}$ concentrations as a proxy for $\mathrm{Au}$. The $\mathrm{Ag}$ concentration is below detection in the 5-10 ppm range which is low for crustal fluids in a mineralized environment (Cerro Rico, Boliva 10's to 100's ppm, Imiter, Moroccoo 10's ppm Ag. Banks pers comm.) and we suggest not sufficient to be a fluid that could precipitate electrum. It may be that what we analysed were not the $\mathrm{Au}-\mathrm{Ag}$ fluids mineralizing fluids, rather the fluids after $\mathrm{Au}$ and $\mathrm{Ag}$ had been deposited elsewhere in the system. The distinctly negative $\delta^{34} S$ values are a good indicator of reduced sulphur originating by boiling. This would occur due to boiling and oxidation of $\mathrm{H}_{2} \mathrm{~S}$ derived from the magma and would be consistent the high $K$ concentrations usually found in acid-sulphate near surface environments and by the fluid inclusion evidence. Similar negative $\delta^{34} S$ values from other locations may indicate that this is a widespread process and could be a useful indicator of boiling zones when conventional mineralogical or fluid inclusion evidence is not present. Textures in the veins, saccharoidal, massive comb to crustiform, colloform and bladed calcite including bladed quartz replacement are suggestive of boiling.

Our interpretation is that mineralization occurred at shallow depth from fluids that cooled by adiabatic expansion as the veins opened and by dilution with meteoric water. Au was most likely deposited due to boiling of the fluids at relatively shallow depths. The present day geographical heights of the deposits would suggest, that at most, only a few hundred metres has been eroded from the deposits.

\section{Acknowledgements}

This study was supported financially by the Research Foundation of Cumhuriyet University (Project No: M454). We wish to acknowledge the Okyanus Mineral Mining Company for allowing us to study in Tesbihdere licensed area. We would like to thank to Graciela Sosa and an anonymous reviewer for their invaluable comments that improved the quality of this paper.

\section{References}

[1] Jingwen M., Pirajno F., Lehmann B., Maocheng L., Berzina A., Distribution of porphyry deposits in the Eurasian continent and their corresponding tectonic settings, Journal of Asian Earth Sciences, 2013, doi: http://dx.doi.org/10.1016/j.jseaes.2013.09.002

[2] Yigit O., A prospective sector in the Tethyan Metallogenic Belt: Geology and geochronology of mineral deposits in the Biga Peninsula, NW Turkey, Ore Geology Reviews 46, 2012, 118-148

[3] Jankovic S., Tethyan Eurasian Metallogenic Belt: Relations of mineral associations and their tectonic setting, Geotectonica et Metallogenia 10, 1986, 99124.

[4] Andic T. \& Kayhan F., Report on the General Geochemical Research of the Çanakkale-Lapseki. Technical Reports of the General Directorate of the 
Mineral Research and Exploration Institute (MTA) of Turkey, 1997. Report no. 10059 (in Turkish, unpublished)

[5] Bozkaya G., Geology of Koru (Çanakkale) barite bearing lead-zinc deposits. PhD Thesis, University of Cumhuriyet, 126 (unpublished), 2001

[6] Bozkaya G., Gökce A., Geology, ore petrography and fluid inclusion characteristics of the Koru (Çanakkale) $\mathrm{Pb}-\mathrm{Zn}$ deposits, Cumhuriyet University Bulletin of the Faculty of Engineering, Series A, Earth Sciences 18, 2001, 55-70

[7] Bozkaya G, Gökce A., Major, trace and rare earth elements geochemistry of the Koru (Çanakkale) leadzinc deposits, Geological Bulletin of Turkey 45, 2002, 1-17

[8] Bozkaya G., Gökce A., Lead and Sulfur Isotope Studies of the Koru (Çanakkale, Turkey) Lead-Zinc Deposit, Turkish Journal of Earth Science 18, 2009, 127-137

[9] Orgün Y., Gültekin A. H., Önal A., Geology, mineralogy and fluid inclusion data from the Arapuçandere $\mathrm{Pb}-\mathrm{Zn}-\mathrm{Cu}-\mathrm{Ag}$ deposit, Çanakkale, Turkey, Journal of Asian Earth Sciences 25, 2005, 629-642

[10] Bozkaya G., Gökce A., Fluid inclusion and isotope geochemistry studies of the galena-barite veins in Balcular (Lapseki-Çanakkale) area. Abstract of $60^{\text {th }}$ Geological Congress of Turkey, 2007, 188-190

[11] Bozkaya G., and Celik S., The origin of hydrothermal fluids in the Kumarlar $\mathrm{Pb}-\mathrm{Zn}$ veins, Canakkale, NW Turkey. 20 $0^{\text {th }}$ General Meeting of the International Mineralogical Association (IMA), Eötvös Lorand University, Budapest, 21-27 August, 2010, Abstract volume, 79

[12] Bozkaya G., Sulfur- and Lead-Isotope Geochemistry of the Arapuçandere (Karaköy-Yenice, Çanakkale) Pb-Zn-Cu Deposit, Biga Peninsula, NW Turkey, International Geology Review 53, 2011, 116-129

[13] Bozkaya G., Sulfur Isotope Composition of the Bagirkacdere lead-zinc deposit, Biga Peninsula, Turkey. Goldschmidt, 14-19 August, 2011, Prag. Abstract Volume, 571

[14] Bozkaya G., Gokce A., Banks D., Bodnar R. J., Epithermal mineralization in Western Turkey:nature and origin of the fluids. European Current Research on Fluid Inclusions (Ecrofi-XX1), University of Leoben, Leoben, Australia, 9-11 August, 2011, Abstract Volume, 52

[15] Yılmaz H., Oyman T., Sönmez F. N., Arehart G. B., Billor Z., Intermediate sulfidation epithermal goldbase metal deposits in Tertiary subaerial volcanic rocks, Șahinli/Tespih Dere (Lapseki/Western Turkey),
Ore Geology Reviews 37, 2010, 236-258

[16] Unal E. I., Gulec N., Kuscu I., Fallick A. E., Genetic investigation and comparison of Kartaldagì and Madendagì epithermal gold deposits in Çanakkale, NW Turkey, Ore Geology Reviews 53, 2013, 204-222

[17] Okay A. I., Siyako M. \& Bürkan K. A., Geology and tectonic of the Biga Peninsula, Turkish Associations of Petroleum Geologists Bulletin 2, 1990, 83-121 (in Turkish with English abstract)

[18] Okay A., Siyako M. \& Bürkan K. A., Geology and tectonic evolution of the Biga Peninsula, Bulletin of the Technical University of Istanbul 44, 1991, 191255

[19] Ercan T., Satir M., Steinitz G., Dora A., Sarifakioglu E., Adis C., Walter H. \& Yildirim T., Characteristic of Tertiary volcanism in the Biga Peninsula and Gökçeada, Bozcaada and Tavșan islands (NW Anatolia), Mineral Research and Exploration Institute (MTA) of Turkey Bulletin 117, 1995, 55-86 [in Turkish with English abstract)

[20] Yılmaz, Y., Allochthonous terranes in the Tethyan Middle East: Anatolia and the surrounding regions: phil, Trans. Roy. Soc. London, 1990, v. A331, 611-624

[21] Yılmaz Y., Genç S. C, Gürer F., Bozcu M., Yılmaz K., Karacık Z, Altunkaynak S., Elmas A., When did the western Anatolian grabens begin to develop? In Tectonics and magmatism in Turkey and the surrounding area, Bozkurt E., Winchester J. A., Piper J. A. D. (eds). Special Publications 173. Geological Society: London; 2000, 131-162

[22] Siyako M., Bürkan K. A. \& Okay A. I., Tertiary Geology and Hydrocarbon Potential of the Biga and Gelibolu Peninsulas, Turkish Associations of Petroleum Geologist Bulletin 1, 1989, 183-199 (in Turkish with English abstract)

[23] Ercan T., Türkecan, A., A general review of the plutons in western Anatolia, Aegean Islands, Greece and Bulgaria. Ketin Symposium, 20-21 February 1984, Ankara. Geological Society of Turkey, 1984, 189-208

[24] Aldanmaz E., Pearce J. A., Thirlwall M. F., Mitchell J. G., Petrogenetic evolution of late Cenozoic, postcollision volcanism in western Anatolia, Turkey, Journal of Volcanology and Geothermal Research 102, 2000, 67-95

[25] Altunkaynak S., Genç, C., Petrogenesis and timeprogressive evolution of the $\mathrm{Ce}$ - nozoic continental volcanism in the Biga Peninsula, NW Anatolia (Turkey), Lithos 102, 2008, 316-340

[26] Genç S. C. \& Yilmaz Y., Evolution of the Triassic continental margin, northwest Anatolia, Tectonophysics 243, 1995, 193-207

[27] Ersoy Y., Helvacı C., Palmer M. R., Stratigraphic, 
structural and geochemical features of the NESW trending Neogene volcano-sedimentary basins in western Anatolia: Implications for associations of supra-detachment and transtensional strike-slip basin formation in extensional tectonic setting, Journal of Asian Earth Sciences 41, 2011, 159-183

[28] Aldanmaz E., Mantle source characteristics of alkali basalts and basanites in an extensional intracontinental plate setting, western Anatolia, Turkey: implication for multi-stage melting, International Geology Review 44, 2002, 440-457

[29] Bozkaya G., Fluid inclusion and stable isotope (O, $\mathrm{H}$ and S) evidence for the origin of the Balcilar vein type barite-galena mineralization in Çanakkale, Biga Peninsula, NW Turkey. GEOFLUIDS VI. Sixth International Conference on Fluid Evolution, Migration and Interaction in Sedimentary Basins and Orogenic Belts, University of Adelaide, South Australia, Australia, 15-18 April. Journal of Geochemical Exploration, Abstracts of Geofluids VI, 101(1), 2009, 8

[30] Schmid R., Descriptive nomenclature and classfication of pyroclastic deposits and fragments: Recommendations of the IUGS Subcomission on the Systematics of Igneous Rocks, Geology 9, 1981, 41-43

[31] Bozkaya Ö., Bozkaya G., Yalcin H., Gokce A., Diagenetic, hydrothermal and surfice alterations in the Eocene aged pyroclastic rocks in the vicinity of Koru $\mathrm{Pb}-\mathrm{Zn}$ deposits. 13 ${ }^{\text {th }}$ National Clay Symposium, 12-14 September 2007, Suleyman Demirel University, Isparta, Proceedings, 2007, 8096

[32] Bodnar R. J., Revised equation and table for determining the freezing point depression of $\mathrm{H}_{2} \mathrm{O}$ $\mathrm{NaCl}$ solutions, Geochim. et Cosmochim. Acta. 57, 1993, 683-684

[33] Guillong M., Meir D. L., Allan M. M., Heinrich C. A. and Yardley B. W. D., SILLS: A Matlab based program for the reduction of Laser Ablation ICP-MS data of homogeneous materials and inclusions, Mineralogical Association of Canada Short Course 40, 2008, 328333

[34] Allan M. M., Yardley B. W. D., Forbes L. J., Shmulovich K. I., Banks D. A. and Shepherd T. J., Validation of LA-ICP-MS fluid inclusion analysis with synthetic fluid inclusions, American Mineralogist 90, 2005, 1767-1775

[35] Banks D. A., Giuliani G., Yardley B. W. D. and Cheilletz A., Emerald mineralization in Colombia: fluid chemistry and the role of brine mixing, Mineralium Deposita 35, 2000, 699-713
[36] Yanagisawa F., Sakai H., Thermal decomposition of barium sulfate-vanadium pentaoxide-silica glass mixtures for preparation of sulfur dioxide in sulfur isotope ratio measurements, Analytical Chemistry 55, 1983, 985-987

[37] Hoefs J., Stable isotope geochemistry, $6^{\text {th }}$ ed.: Berlin Heidelberg, Springer-Verlag, 2009, 285

[38] Chaussidon, M. and Lorand J. P., Sulphur isotope composition of orogenic spinel therzolite massifs from Ariege (North-Eastern Pyrenees, France): an ion microprobe study, Geochim. Cosmochim. Acta 54, 1990, 2835-2846

[39] Chaussidon M., Albarède F., Sheppard S. M. F., Sulphur isotope variations in the mantle from ion microprobe analyses of micro-sulphide inclusions, Earth and Planetary Science Letters 92, 1989, 144156

[40] Rollinson H. R., Using geochemical data: evaluation, presentation, interpretation. Longman, Harlow, 1993, 352

[41] Yilmaz H., Oyman T., Arehart G. A., Colakoglu R. and Billor Z., Low sulphidation type Au-Ag mineralization at Bergma, Izmir, Turkey, Ore Geology Reviews 32, 2007, 81-124

[42] Yigit O., Mineral deposits of Turkey in relation to Tethyan metallogeny: Implications for future mineral exploration, Economic Geology 104, 2009, 19-51

[43] Fournier R. O. and Truesdell A. H., An empirical NaK-Ca geothermometer for natural waters, Geochim. et Cosmochim. Acta 37, 1973, 1255-1275

[44] Yardley B. W. D., Metal concentrations in crustal fluids and their relationship to ore formation, Economic Geology 100(4), 2005, 613-632

[45] Audetat A., Pettke T., Heinrich C. A. and Bodnar R. J., The composition of magmatic-hydrothermal fluids in barren and mineralized intrusions, Economic Geology 103(5), 2008, 877-908

[46] Pudack C., Halter W. E., Heinrich C. A. and Pettke T., Evolution of magmatic vapour to goldrich epithermal liquid: The porphyry to epithermal transition at Nevados de Famatina, Northwest Argentina, Economic Geology 104(4), 2009, 449-477

[47] Drummond S. E. and Ohmoto H., Chemical evolution and mineral deposition in boiling hydrothermal systems, Economic Geology 80, 1985, 126-147

[48] Duuring P., Rowins S. M., McKinley B. S .M., Dickinson J. M., Diakow L. J., Kim Y. S. and Creaser R. A., Examining potential genetic links between Jurassic porphyry $\mathrm{Cu}-\mathrm{Au} \pm \mathrm{Mo}$ and epithermal $\mathrm{Au}$ $\pm \mathrm{Ag}$ mineralization in the Toodoggone district of north-central British Columbia, Canada: Mineralium Deposita 44, 2009, 463-496 
[49] Kamvong T. and Zaw K., The origin and evolution of skarn-forming fluids from the Phu Lon deposit, northern Loei fold belt, Thailand: Evidence from fluid inclusion and sulfur isotope studies, Journal of Asian Earth Sciences 34, 2009, 624-633

[50] McKibben M. A. and Eldridge C. S., Radical sulphur isotope zonation of pyrite accompanying boiling and epithermal gold deposition: A SHRIMP study of the Valles caldera, New Mexico, Economic Geology 85, 1990, 1917-1925

[51] Bethke P. M., Rye R. O., Stoffregen R. E. and Vikre P. G., Evolution of the magmatic-hydrothermal acid-sulphate system at Summitville, Colorado: Integration of geological, stable-isotope, and fluid inclusion evidence, Chemical Geology 215, 2005, 281-315

[52] Hedenquist J. W., Simmons S. F., Giggenbach W. F. and Eldridge C. S., White Island, New Zealand, volcanic-hydrothermal system represents the geochemical environment of high-sulphidation $\mathrm{Cu}$ and Au deposition, Geology 21, 2013, 731-734

[53] Brown K. L., Gold deposition from geothermal discharges in New Zealand, Economic Geology 81, 1986, 979-983

[54] Bottrell S. H. and Yardley B. W. D., The composition of a primary granite-derived ore fluid from SW England determined by fluid inclusion analysis, Geochim. Cosmochim. Acta 52, 1988, 585-588

[55] Yigit O., A prospective sector in the Tethyan Metallogenic Belt: Geology and geochronology of mineral deposits in the Biga Peninsula, NW Turkey, Ore Geology Reviews 46, 2012, 118-148

[56] Haas J. L. Jr., The effect of salinity on the maximum thermal gradient of a hydrothermal sytem at hydrostatic pressure, Economic Geology 66, 1971, 940-46

[57] Li Y. and Liu J., Calculation of sulfur isotope fractionation in sulfides, Geochim. Cosmochim. Acta 70, 2006, 1789-1795 